NBER WORKING PAPER SERIES

\title{
BANKS, SOVEREIGN DEBT AND THE INTERNATIONAL TRANSMISSION OF BUSINESS CYCLES
}

Luca Guerrieri

Matteo Iacoviello

Raoul Minetti

Working Paper 18303

http://www.nber.org/papers/w18303

\author{
NATIONAL BUREAU OF ECONOMIC RESEARCH \\ 1050 Massachusetts Avenue \\ Cambridge, MA 02138 \\ August 2012
}

The views expressed in this paper are solely the responsibility of the authors and should not be interpreted as reflecting the views of the Board of Governors of the Federal Reserve System, any other person associated with the Federal Reserve System, or the National Bureau of Economic Research. Replication codes and an Appendix containing detailed derivations are available from the authors upon request.

NBER working papers are circulated for discussion and comment purposes. They have not been peerreviewed or been subject to the review by the NBER Board of Directors that accompanies official NBER publications.

(C) 2012 by Luca Guerrieri, Matteo Iacoviello, and Raoul Minetti. All rights reserved. Short sections of text, not to exceed two paragraphs, may be quoted without explicit permission provided that full credit, including $(\mathcal{C}$ notice, is given to the source. 
Banks, Sovereign Debt and the International Transmission of Business Cycles

Luca Guerrieri, Matteo Iacoviello, and Raoul Minetti

NBER Working Paper No. 18303

August 2012

JEL No. F4,G21,H63

\section{$\underline{\text { ABSTRACT }}$}

This paper studies the international propagation of sovereign debt default. We posit a two-country economy where capital constrained banks grant loans to firms and invest in bonds issued by the domestic and the foreign government. The model economy is calibrated to data from Europe, with the two countries representing the Periphery (Greece, Italy, Portugal and Spain) and the Core, respectively. Large contractionary shocks in the Periphery trigger sovereign default. We find sizable spillover effects of default from Periphery to the Core through a drop in the volume of credit extended by the banking sector.

Luca Guerrieri

The Federal Reserve Board

Mail Stop 20

20th and C Street, N.W.

Washington, D.C. 20551

luca.guerrieri@frb.gov

Matteo Iacoviello

Federal Reserve Board

Mail Stop 20

20th and $\mathrm{C}$ st NW

Washington DC 20551

matteo.iacoviello@frb.gov
Raoul Minetti

Michigan State University

minetti@msu.edu 


\section{Introduction}

In the last fifteen years, following the introduction of the euro and the resulting elimination of exchange rate risk among euro area members, European banks have increasingly, "happily owned regional, rather than merely national, government bond portfolios" (The Economist, 2012). In particular, banks of the core European countries (e.g., France and Germany) have turned into major holders of the sovereign debt of periphery countries, such as Greece, Italy, Portugal and Spain. For instance, combining data from the Bank for International Settlements with data from the Bank of France reveals that in the last quarter of 2009, just before the outbreak of the eurozone sovereign debt crisis, the ratio of French banks' holdings of Periphery's sovereign debt over their holdings of French government debt equaled 56 percent, up from 19 percent in the first quarter of 2005. Figure 1 plots various ratios for French banks' holdings of Periphery's sovereign debt from the first quarter of 2005 to the third quarter of 2011. ${ }^{1}$ The figure shows a dramatic increase in the holdings of Periphery sovereign debt by French banks, whether these are normalized by banks' total assets, their holdings of French government debt or by the total sovereign debt of Periphery countries. ${ }^{2}$

During the current sovereign debt crisis in Europe, the large holdings of government bonds accumulated in recent years have significantly exposed European banks to the default risk of periphery countries. This has been exacerbated by the fact that, as shown by the restructuring of Greek sovereign debt in March 2012, banks and other private investors are treated as junior creditors relative to official investors (e.g., the central banks of the Eurosystem) during sovereign debt restructurings. ${ }^{3}$ European banks have thus suffered from a sizable erosion of their capitalization and a severe difficulty to tap wholesale funding and interbank markets. Allegedly, this has resulted, in turn, into reduced ability and propensity to extend credit to firms.

The propagation of sovereign default to the banking sector and, ultimately, to the corporate sector poses challenges that have been largely unexplored, thus far. A first question regards the magnitude of the possible effects. How large can a bank credit crunch induced by a sovereign debt crisis be and how important the international spillovers? Second, how does the degree of banks' exposure

\footnotetext{
${ }^{1}$ We choose data for France since analogous data for German banks are available only starting in 2010 Q4.

${ }^{2}$ The holdings of Belgian, Italian and Spanish government debt exceeded the tier 1 capital of banks in the three countries and 50 percent of the tier capital of banks in France and Germany (see Shambaugh, 2012).

${ }^{3}$ The restructuring of Greek debt in March 2012 involved bonds for a total value of about 199 billion Euros. The exchange of new bonds for old ones reduced the face value of bonds by almost 55 percent.
} 
to foreign sovereign debt affect the transmission of shocks across countries ${ }^{4}$ If banks deleverage by selling government bonds, they will aggravate the financing problems of the government, but will avoid a credit crunch on firms. If instead banks deleverage by contracting credit to the corporate sector, they will not exacerbate the funding pressures on the government, but their actions will push up firms' financing costs. ${ }^{5}$ In an international setting, these issues are more complex since banks hold both domestic and foreign government bonds and may also deleverage by scaling down their holdings of foreign government bonds.

To answer these questions, we develop an equilibrium business cycle model. The model features two country blocs, Periphery (Greece, Italy, Portugal and Spain) and Core (the rest of the Europe). Prices and wages are assumed to be flexible, so that, absent sovereign default, our model behaves not too differently from a standard international real business cycle model. In each bloc there are households, entrepreneurs, final good firms, and a government. In addition, in each bloc a banking sector intermediates funds between households and entrepreneurs. Households supply labor to domestic entrepreneurs and deposit savings in local banks. Banks, in turn, grant loans to entrepreneurs and invest in bonds issued by the domestic and the foreign government. Agents in both countries derive utility from consumption. In each country, entrepreneurs produce final goods using capital and labor. Banks are subject to an exogenous capital requirement that constrains their supply of loanable funds. The government maximizes the utility from its expenditure, finances itself through taxes and bonds and can choose to default on its outstanding debt. In each period, its debt capacity is related to its repayment history, reflecting the possibility that default induces punishment in the form of partial exclusion from financial markets.

We use the model to understand cause and effects of sovereign default. Regarding the cause, default occurs when contractionary shocks in a country are large enough that the government prefers to stop honoring its debt in order to curb the contraction in spending. Regarding the consequences of default, we decompose them in two effects, a debt repudiation effect, and a punishment effect. Repudiation represents a transfer of wealth from banks and domestic households to the government.

\footnotetext{
${ }^{4}$ In the analysis, we abstract from the interbank market and posit that banks fund themselves through retail deposits and equity.

${ }^{5}$ During the eurozone crisis, banks of core European countries have only slightly decreased or increased their holdings of domestic government debt. By contrast, they have reduced both their holdings of foreign government bonds and the credit extended to firms.
} 
This wealth transfer affects both the decision of banks to make loans and the saving decision of households. Debt repudiation has a negative effect on output both in the core and in the periphery, with the size of the effect depending, intuitively, on the relative shares of government debt held by households and banks. In particular, debt repudiation erodes the capitalization of both domestic and foreign banks. In the presence of binding capital requirements, this erosion forces banks to contract their loans, causing a drop of investment and output. The punishment effect, instead, is nothing else but the deleveraging of the government caused by reduced access to credit markets after default. We find that the punishment may have opposite effects on output in the core and in the periphery: under our preferred calibration, the punishment may force a portfolio rebalancing that cushions the negative effects of default on output in the periphery (since banks stop buying government debt and make more loans to Periphery firms), while worsening it in the core.

To explore the quantitative implications of our model, we calibrate it so that the Periphery is

Greece, Italy, Portugal, and Spain, and the Core is the rest of the euro area, together with Switzerland and the United Kingdom. Under our benchmark calibration, a partial default on the sovereign debt of the Periphery, sized to equal 10 percent of Periphery GDP (or 12 of Periphery debt) and, taking into account relative sizes, about 3 percent of Core GDP, lowers Core and Periphery GDP by almost half a percent after two years. To relate this calibration to recent events, the default we consider is equivalent to roughly twice the size of the Greek debt restructuring in March 2012.

The remainder of the paper is organized as follows. Section 2 relates the paper to the literature. Section 3 describes the model. Section 4 presents the calibration and the solution method. Section 5 discusses the results. Section 6 concludes.

\section{$2 \quad$ Related Literature}

There are very few studies on the role of banks and supply-side credit market imperfections in global economies. In addition, these studies do not focus on sovereign debt problems. Devereux and Yetman (2010) study a two-country economy in which investors hold assets in the domestic and the foreign country but are exposed to leverage constraints. They find that if international financial markets are highly integrated, productivity shocks will be propagated through investors' financial portfolios. In turn, this will generate a strong output comovement between the two countries. Mendoza and Quadrini 
(2010) consider a two-country model with a different degree of financial development in each country, as captured by households' ability to insure against income shocks. They investigate cross-country spillover effects of shocks to bank capital. Both Kollmann, Enders and Muller (2011) and KalemliOzcan, Papaioannou and Perri (2011) consider a two-country environment with a global banking sector. When a shock erodes the capitalization of global banks, it reduces credit supply and depresses economic activity in both countries. ${ }^{6}$ In particular, banks' losses raise bank intermediation costs in both countries, triggering synchronized business fluctuations. Kamber and Thonissen (2012) analyze the international transmission of shocks in a global economy in which banking sectors are mostly independent: banks in the large economy do not lend to firms in the small economy. Ueda (2012) constructs a two-country model in which financial intermediaries stipulate chained credit contracts domestically and abroad (that is, they engage in cross-border lending by undertaking cross-border borrowing from investors). His analysis reveals that negative shocks to one country propagate to the other, strengthening international comovement. ${ }^{7}$

Our paper also relates more broadly to the literature on financial imperfections in open economies. A growing body of research finds that credit market imperfections help explain some of the features of the international transmission of business cycles that cannot be explained by RBC models. Backus, Kehoe and Kydland (1992), Baxter and Crucini (1995) and Heathcote and Perri (2002) find that restrictions in the trade of financial assets can account for the positive output correlation across countries by reducing international capital mobility. More recently, papers such as Kehoe and Perri (2002), Iacoviello and Minetti (2006) and Gilchrist, Hairault and Kempf (2002) have analyzed models in which agents face borrowing constraints when tapping international financial markets. The presence of borrowing constraints amplifies the international transmission of shocks. In Dedola and Lombardo (2012) and Perri and Quadrini (2010) firms face borrowing constraints due to limited credit contract enforceability. In their environments, tighter borrowing constraints in one country can induce a contraction in economic activity in the other country. ${ }^{8}$

\footnotetext{
${ }^{6}$ Gilchrist (2004) models a financial accelerator in a two-country model where the two countries feature different leverage. Shocks are transmitted internationally by affecting foreign borrowers' net worth.

${ }^{7}$ Other papers in this literature include Olivero (2010) and Gerali, Neri, Sessa and Signoretti (2010). Olivero (2010) investigates an imperfectly competitive global banking system and examines how changes in banks' markup can propagate shocks internationally.

${ }^{8}$ In Dedola and Lombardo (2012) investors hold both domestic and foreign capital stock but can only borrow from the domestic capital market in a model with financial frictions as in Bernanke, Gertler and Gilchrist (1999).
} 
On the modeling front, our analysis is also related to the growing literature on the role of banks and bank capital in general equilibrium closed-economy models. Papers in this literature include Gertler and Karadi (2010) and Gertler and Kiyotaki (2010). ${ }^{9}$ Banks do not hold government debt in these papers.

Finally, our paper is also related to the literature on the macroeconomic consequences of sovereign default. The empirical literature is vast but has to confront the difficult problem of separating cause and effect of default. The survey by De Paoli, Hoggart and Saporta (2006) is an example: they find that output losses in the wake of sovereign default are around 7 percent per year, but note that it is difficult to separate the loss due to default per se from the loss caused by the shock that triggered default. Sturzenegger (2004), using annual data, finds that growth in the defaulting country falls by 0.6 percentage points per year after default. Instead, Levy Yeyati and Panizza (2011), using quarterly data for a panel of countries, find that default marks the beginning of the recovery in the country that defaults. On the modeling front, Mendoza and Yue (2012) construct a small open economy model of sovereign default and business cycles: their model does not study the international transmission of business cycles when default takes place, which is instead the main focus of our analysis.

\section{The Model}

This section describes the set-up of the model, solves for agents' decisions, and characterizes the equilibrium.

\subsection{Environment}

The world economy consists of two countries, Core and Periphery. In each country there are infinitelylived households, entrepreneurs (capital good producers), final good producers, bankers. All agents of a given type are homogeneous. In addition, in each country there is a government that purchases final goods financing its expenditures with debt and lump-sum taxes. In the world economy there is one final good (tradeable internationally at no cost). The final good is produced using labor (nontradeable internationally) and capital. ${ }^{10}$ All markets are competitive. The Periphery and the Core

\footnotetext{
${ }^{9}$ See also, e.g., Den Haan, Ramey and Watson (2004), Minetti (2007), and Iacoviello (2011).

${ }^{10}$ In the tradition of Backus, Kehoe and Kydland (1992), we do not allow for labor mobility between the two country blocs. Labor mobility across countries can affect the responsiveness of labor supply to the wage rate within a country.
} 
have symmetric preferences and technology. In what follows, we concentrate on the description of the Periphery, denoting the variables of the Core country by an asterisk $(*) .{ }^{11}$

Agents' activities are as follows. In each period, households supply labor to entrepreneurs. Households can save in three ways: they can invest in physical capital, which they rent to final good producers; they can hold deposits in domestic banks; they can purchase noncontingent bonds issued by the domestic government. ${ }^{12}$ Entrepreneurs receive loans from banks and invest into physical capital, which they rent to final good producers. Final good producers produce the final good using labor and capital. Bankers receive deposits, make loans to domestic entrepreneurs and purchase bonds issued by the domestic and the foreign government. In each period, final good producers interact with households in the labor market and in the market for capital and with entrepreneurs in the market for capital; bankers interact with entrepreneurs in the credit market.

\subsection{Households}

There is a continuum of identical infinitely-lived households, who derive utility from consumption and from leisure. The representative household maximizes its expected utility

$$
E_{s}\left\{\sum_{t=s}^{\infty} \beta_{H}^{t-s} u\left(C_{H, t}, N_{H, t}\right)\right\},
$$

where $E_{s}$ denotes the expectation operator conditional on the information available in period $s, \beta_{H}$ is the household's subjective discount factor, $C_{H, t}$ is its consumption, $N_{H, t}$ is its labor supply. As explained below, differences in the subjective discount factor across households, bankers, and entrepreneurs give rise to borrowing and lending.

Equation (2) shows the budget constraint of the representative household:

$$
\begin{aligned}
& C_{H, t}+D_{t}+B_{H, t}+T_{t} \\
= & R_{D, t} D_{t-1}+R_{B, t-1} B_{H, t-1}-\frac{B_{H, t-1}}{B_{t-1}} \zeta_{t}+W_{t} N_{H, t}+A C_{H, t},
\end{aligned}
$$

where $D_{t}$ are the household's holdings of deposits in domestic banks, and $B_{H, t}$ are the holdings of domestic government bonds. $R_{D, t}$ and $R_{B, t-1}$ are, respectively, the gross interest rates on deposits

\footnotetext{
Accordingly, its effects may be partially captured through appropriate choice of the wage elasticity of labor supply.

${ }^{11}$ Our model features perfect substitutability between goods produced at home and abroad.

${ }^{12}$ For simplicity, we do not allow households to hold foreign government debt and foreign deposits. The amount of foreign government bonds held by households directly (i.e., without the intermediation of the banking sector) is very small.
} 
and government bonds between period $t-1$ and period $t$. Notice that the return on deposits is assumed to be predetermined. $W_{t}$ is the wage rate, and $T_{t}$ is a lump-sum tax imposed on households by the government. In any period, after agents purchase government debt, the government may decide to default. The term $\zeta_{t}$ captures the loss borne by households from government default, where $\frac{B_{H, t-1}}{B_{t-1}}$ is the share of outstanding government bonds $B_{t-1}$ held by households. $\zeta_{t}$ takes non-negative values and is equal to zero unless (partial) sovereign default occurs. Finally, the term $A C_{H, t}$ denotes quadratic portfolio adjustment costs (we specify the functional form in the calibration section) which are paid by the household to change the holdings of $D_{t}$, and to change the holdings of $B_{H, t}$ relative to a target steady-state level. These costs make the households' supply of deposits, bonds and capital less sensitive to interest rate differentials. ${ }^{13}$

Using the first-order conditions for the household's problem with respect to consumption and government debt holdings, one obtains the following Euler condition:

$$
\frac{\partial u\left(C_{H, t}, N_{H, t}\right)}{\partial C_{H, t}}=\beta_{H} E_{t}\left[\left(R_{B, t}-\frac{\zeta_{t+1}}{B_{t}}\right) \frac{\partial u\left(C_{H, t+1}, N_{H, t+1}\right)}{\partial C_{H, t+1}}\right] .
$$

From this condition, it is easy to see that the expectation of default affects the effective rate of return from bond holding. Accordingly, equilibrium interest rates will adjust to the extent that government default is anticipated.

The remaining optimality conditions for the households with respect to bank deposits, capital holdings and labor supply are standard. The households' optimality conditions will imply that in an interior steady state the households will demand both deposits and government bonds when their return equals the households' discount rate, $1 / \beta_{H}-1$.

\subsection{Bankers}

Bankers collect deposits from domestic households, make loans to domestic entrepreneurs, and hold domestic and foreign government bonds. Since the banking sector is perfectly competitive, banks take interest rates prevailing in the domestic and foreign bond and credit markets as given. The

\footnotetext{
${ }^{13}$ We solve our model using first-order approximations around the deterministic steady state. In principle, given the total supply of government debt, the relative holdings of households and banks could be solved for endogenously using the methods described in Devereux and Sutherland (2011); this would in turn require specifying a richer stochastic structure for our model economy, an approach that we do not pursue here.
} 
representative banker maximizes expected discounted utility

$$
E_{s}\left[\sum_{t=s}^{\infty} \beta_{B}^{t-s} u\left(C_{B, t}\right)\right],
$$

where $C_{B, t}$ denotes the banker's consumption, and $\beta_{B}$ is its discount factor. The flow budget constraint of a banker is

$$
\begin{aligned}
& C_{B, t}+R_{D, t} D_{t-1}+L_{t}+B_{B, t}+B_{F, t} \\
= & D_{t}+R_{L, t} L_{t-1}+R_{B, t-1} B_{B, t-1}+R_{B, t-1}^{*} B_{F, t-1} \\
& -\frac{B_{B, t-1}}{B_{t-1}} \zeta_{t}-\frac{B_{F, t-1}}{B_{t-1}^{*}} \zeta_{t}^{*}+A C_{B, t},
\end{aligned}
$$

where $L_{t}$ denotes loans to entrepreneurs, $B_{B, t}$ and $B_{F, t}$ are the banker's holdings of domestic and foreign government bonds respectively. The terms $\zeta_{t}$ and $\zeta_{t}^{*}$ measure the losses that are borne by the bankers in case of domestic and foreign sovereign debt defaults. Like for the household problem, $A C_{B, t}$ denotes quadratic adjustment costs for changing $L_{t}, B_{B, t}, B_{F, t}$, and $D_{t}{ }^{14}$

Bankers are subject to a capital constraint that specifies that the value of the loans they extend cannot exceed a certain fraction of the value of their net worth. The capital constraint reads as:

$$
D_{t} \leq \gamma_{L} L_{t}+B_{B, t}+B_{F, t}
$$

where $\gamma_{L}<1$. We assume that the bankers' discount factor $\beta_{B}$ is lower than the households'. This relative impatience assumption implies that the bankers' capital constraint binds with equality in a neighborhood of the steady state.

The capital constraint in Equation 6 is aimed at capturing both regulatory-driven and marketdriven capital requirements. In the case of loans, the constraint puts a limit on the leverage of the bank since it requires that, for each unit of loans extended, the bank set aside $1-\gamma_{L}$ units of goods as bank capital. As a consequence, the equilibrium return on loans will be higher than the return on government bonds (and higher than the cost of deposits) in order to compensate the bank for the relative illiquidity/non-pledgeability of loans relative to government bonds. The assumption that

\footnotetext{
${ }^{14} \mathrm{~A}$ possible extension of the bankers' problem would allow for costs of managing loans. These costs would introduce a wedge between the loan rate and the deposits rate, which would compensate banks for their intermediation cost. Without time variation in this wedge, the model would be little changed. Furthermore, notice that intermediation costs are not absent from our setup. The adjustment costs on bank loans capture costs of granting new loans or redeeming existing ones.
} 
$\gamma_{L}<1$ implies that loans and deposits are not perfect substitutes for the bank, and that loans provide, loosely speaking, lower utility to the bank, the lower $\gamma_{L}$ is.

For the banker to be indifferent between financing its operations through loans and deposits, the interest rate on loans adjusts in equilibrium to compensate the banker for the relative illiquidity of loans. This happens because all bankers are identical (and subject to the same constraint) and because markets are incomplete - only bankers have the technology to make loans. The nature of the bank problem described here extends the closed-economy formulation of Iacoviello (2011) to an open economy setting and to the case where banks can hold more than one asset. We also assume that government bonds are fully collateralizable by the bank (that is, the bank can collect one dollar of deposits and buy one dollar of government bonds without having to set aside any net worth), in line with standard features of capital regulation. ${ }^{15}$

The modelling of the bankers' problem in our model abstracts from various realistic features. Liabilities consist of deposits only and there is no separate category of bank bonds. ${ }^{16}$ However, in the absence of an explicit notion of asset liquidity, deposits closely resemble simple forms of bank bonds. Thus, they can also be considered to be broadly representative of bank bonds. Another simplification in our model is that banks cannot issue new outside equity. In practice, banks face several obstacles in issuing new equity, especially during contractionary phases of the business cycle. First of all, existing shareholders do not favor a dilution of the value of their equity holdings. Second, issuing new equity, especially when market conditions are unfavorable, can be prohibitively costly. ${ }^{17}$ For example, following a negative shock, banks with troubled portfolios have greater incentives to issue equity than banks with higher quality portfolios. If investors cannot distinguish between troubled banks and healthy ones, a standard lemon problem arises and equity issues may only occur with substantial price discounts.

\footnotetext{
${ }^{15}$ The Basel accords imply that government bonds are attributed a zero weight risk in the calculation of regulatory capital ratios. Currently, there is a debate on whether government bonds should be assigned a positive weight in the computation of the TIER 1 ratio. For the households' problem to have an interior solution, one requires that the steady state return on government bonds equals the steady state return on deposits. Since bankers receive deposits from households and also purchase government bonds, imposing that government bonds are not fully collateralizable for the bank would imply that banks would not want to purchase government bonds, since deposits would always be cheaper as a source of financing.

${ }^{16}$ Similar assumptions are made in Hartley (1998), Hartley and Walsh (1991), Christiano, Motto and Rostagno (2003) and Goodfriend and McCallum (2007).

${ }^{17}$ See for instance the Basel II Accord notes, paragraph $757 \mathrm{c}$.
} 


\subsection{Entrepreneurs}

In each country, there is a continuum of identical infinitely-lived entrepreneurs who maximize the following expected lifetime utility

$$
E_{s}\left[\sum_{t=s}^{\infty} \beta_{E}^{t-s} u\left(C_{E, t}\right)\right],
$$

where $\beta_{E}$ is the entrepreneur's subjective discount factor, and $C_{E, t}$ is the entrepreneur's consumption. Entrepreneurs are less patient than households and bankers. ${ }^{18}$ Entrepreneurs transform loans into capital and into consumption using a one-for-one technology. The capital good they produce is rented out to final good producers. In each period, the representative entrepreneur borrows from bankers, produces and rents capital, repays debt, and consumes. The flow budget constraint is:

$$
C_{E, t}+K_{t}+R_{L, t} L_{t-1}=R_{K, t} K_{t-1}+(1-\delta) K_{t-1}+L_{t}+A C_{E, t},
$$

where $K_{t}$ is the capital stock owned by the entrepreneur, $R_{L, t}$ is the gross interest rate on loans between period $t-1$ and period $t, R_{K, t}$ is the rental rate of capital paid to entrepreneurs by final good producers, and $A C_{E, t}$ are quadratic adjustment costs for changing $K$ and $L_{t}$ between one period and the next. Entrepreneurs are subject to a constraint that limits their leverage to a fraction $m$ of their capital holdings:

$$
L_{t}=\rho_{E} L_{t-1}+\left(1-\rho_{E}\right) m K_{t},
$$

where the parameter $\rho_{E}$ dictates how elastic is the loan limit to the current capital choice of the entrepreneur.

\subsection{Final good producers}

The representative final good producer operates a Cobb-Douglas production function given by

$$
Y_{t}=F\left(A_{t}, K_{t-1}, N_{t}\right)=A_{t} K_{t-1}^{\alpha} N_{t}^{1-\alpha},
$$

\footnotetext{
${ }^{18}$ We assume that entrepreneurs are impatient relative to bankers and that bankers are impatient relative to households. The assumption that discount factors are heterogeneous across agents is typically made in macroeconomic models with financial imperfections (see, e.g., Kiyotaki and Moore, 1997). Implicitly, we also assume that the markets are segmented, so that banks are essential in order to intermediate funds between households who want to save and entrepreneurs who want to borrow. These assumptions ensure that in the steady-state equilibrium there is borrowing and lending between the household and the bankers (through deposits), and borrowing and lending between the bankers and the entrepreneurs (through loans).
} 
where $Y_{t}$ is the output of domestic final good, $K_{t}$ is the capital stock rented from entrepreneurs, $N_{t}$ is the labor input and $A_{t}$ denotes a stochastic process for productivity. Producers simply maximize period by period revenues, make zero profits because of perfect competition and constant returns to scale, and equate the marginal product of each factor to its rental cost.

\subsection{Government}

Government spending is financed through taxes on households and through debt. The government budget constraint is

$$
G_{t}+R_{B, t-1} B_{t-1}=B_{t}+T_{t}+\zeta_{t}
$$

where $G_{t}$ is government spending and $B_{t}$ is government debt. Taxes $T_{t}$ are governed by the following reaction function:

$$
T_{t}=\left(1-\rho_{T}\right) \bar{t} Y_{t}+\rho_{T} T_{t-1}
$$

Government debt is held by households, domestic and foreign banks (that is, $B_{t}=B_{H, t}+B_{B, t}+B_{F t}^{*}$ ). We assume that the government is myopic and seeks to maximize current expenditure. ${ }^{19}$ The term $\zeta_{t}$ in equation (11) captures the partial default on previously contracted debt obligations. We restrict $\zeta_{t}$ to take only two values - either zero in the non-default state, or some positive value $\zeta$ if partial default occurs.

Given its myopic objective, the government could in principle try to borrow as much as possible today in order to maximize its expenditures $G_{t}$. We impose a limit to the government ability to raise funds in financial markets, with the tightness of the constraint being related to the government debt repayment history. The debt-ceiling constraint takes the form

$$
B_{t} \leq\left(1-\rho_{B}\right) \bar{b} Y_{t}+\rho_{B} B_{t-1}-p_{t}
$$

The specification of the debt ceiling in Equation (13) follows a large body of literature in international finance (for a review, see Obstfeld and Rogoff, 1996, ch. 6). ${ }^{20}$ When the parameter $\rho_{B}$ is zero, the

\footnotetext{
${ }^{19}$ The literature frequently makes the assumption of government myopia in order to rationalize the observed high levels of sovereign debt as well as other government behaviors. See, e.g., Grossman and Van Huyck (1988), and Grilli, Masciandaro and Tabellini (1991); see also Rieth (2011) for a recent discussion and review of the literature.

${ }^{20}$ According to Obstfeld and Rogoff $(1996, \mathrm{ch} .6)$, a possible theoretical foundation for this specification is that output serves as collateral that backs sovereign debt. For example, in the event of default creditors can seize the output of their sovereign debtor.
} 
debt ceiling only depends on current output $Y_{t}$ and captures restrictions codified in the Maastricht Treaty. Values of $\rho_{B}$ greater than zero allow for dependence of the current debt ceiling on the limit in the previous period. In the event of default, the term $p_{t}$ denotes a punishment triggered through an immediate reduction in the debt ceiling, where

$$
p_{t}=\left\{\begin{aligned}
(\bar{b}-\underline{b}) Y_{t} & \text { if default occurs } \\
\rho_{p} p_{t-1} & \text { otherwise }
\end{aligned}\right.
$$

The parameter $\rho_{p}$ governs the persistence of the punishment. With $\rho_{p}<0$, eventually $p_{t}$ returns to zero. The parameters $\underline{b}$ and $\zeta$ are chosen so that, in the non-stochastic steady state, default is punished with a reduction of the debt ceiling large enough to imply a fall in government spending. Only when shocks, through their effects on $Y_{t}$, lead to a large enough reduction in the debt ceiling does the government find it convenient to default. ${ }^{21}$

This specification of the government's problem allows to endogenize the government's decision to default. This endogenization relates the occurrence and persistence of default episodes to the evolution of key macroeconomic variables. ${ }^{22}$

\section{Calibration and Solution}

We choose the relative size of technology in the two country blocs so that the relative size of output between Periphery and Core is $1 / 3$ in the non-stochastic steady state. This choice reflects the size of nominal GDP at the end of 2010 for Greece, Italy, Portugal and Spain relative to the rest of the euro area together with the United Kingdom and Switzerland. Unless otherwise stated, we adopt the same parametric choices for the two country blocs.

\footnotetext{
${ }^{21}$ For instance, suppose that $\rho_{T}=\rho_{B}=0$. The government maximum expenditure without default is

$$
G_{t}^{N D}=\bar{b} Y_{t}-R_{t-1} B_{t-1}+\bar{t} Y_{t}
$$

while expenditure with default is

$$
G_{t}^{D}=\underline{b} Y_{t}+\zeta-R_{t-1} B_{t-1}+\bar{t} Y_{t}
$$

If $Y_{t}<\frac{\zeta}{\bar{b}-\underline{b}}$, then $G^{D}>G^{N D}$, and the government finds it convenient to default.

${ }^{22}$ In this paper we only consider the effects of shocks starting from steady state allocations. When considering longer sequences of innovations to the shock processes in the model, one would also have to check the additional constraint that the amount of debt repudiated cannot the outstanding obligations.
} 
We choose log utility over consumption for entrepreneurs and bankers. As for households, following Greenwood, Hercowitz, and Huffman (1988), we choose a specification of the form:

$$
u=\log \left(C_{H, t}-\frac{1}{1+\eta}\left(N_{H, t}\right)^{1+\eta}\right) .
$$

The Households' discount factor, $\beta_{H}$, is set to 0.9925 , implying an annual interest rate on deposits and bonds of 3 percent, given that the unit of time is one quarter. $\eta$ is set to 3 , implying a Frisch labor supply elasticity equal to $1 / 3$. The discount factors of bankers and entrepreneurs are set equal to 0.965 and 0.96 , respectively.

On the production side, the depreciation rate $\delta$ is 0.03 and the capital share in production $\alpha$ is 0.33. The investment adjustment cost function takes the form $\phi_{I}\left(\frac{I_{t}}{I_{t-1}}-1\right)^{2}$. We set $\phi_{I}=5$ in order to mimic a relative volatility (standard deviation) of investment to output of around 3 , like in the data. Entrepreneurs also pay a convex cost for adjusting loans of the form $\phi_{L E}\left(\frac{L_{t}}{L_{t-1}}-1\right)^{2}$. We set $\phi_{L E}=0.05$. Capital adjustment costs are a typical feature of closed and open economy models. They help dampen the volatility of investment over the business cycle (see, e.g., Mendoza, 1991). Changing the capital stock of a business involves disruption costs for installation of new machines and plants. Indeed, this process often entails delivery lags and time to install and/or build. Moreover, a costly process of learning may be necessary to adapt to a new structure of production. Finally, secondary markets for capital goods are often thin. This makes many projects irreversible, generating further adjustment costs. We set the parameter governing entrepreneurs' working capital constraint, $m$ equal to 0.90 , and set $\rho_{E}=0.75$.

Moving to the government, the debt ceiling parameter $\bar{b}$ is 3.4 for the Periphery bloc and 2.38 for the Core bloc. These choices imply a debt-to-GDP ratio equal to 0.85 in the Periphery and 0.6 in the Core, in line with data from the IMF Economic Outlook for 2010. The value for $\underline{b}$ (the debt ceiling parameter when punishment takes place) is instead 3 for the Periphery, and an arbitrarily low value for the Core bloc. With the latter choice, the Core bloc never finds it optimal to default. In the tax rate reaction function (equation 13), we set $\rho_{T}=0.5$ and $\bar{t}=0.24$. As for the persistence of the government debt ceiling, we set $\rho_{B}=0.5$. In case of default, the punishment is governed by an autoregressive process with persistence $\rho_{p}=0.5$.

Households pay a cost for adjusting deposits of the form $\phi_{D H}\left(\frac{D_{t}}{D_{t-1}}-1\right)^{2}$. We set $\phi_{D H}=0.05$. The adjustment cost function for sovereign bonds held by households takes the form $\phi_{B H}\left(\frac{B_{H, t}}{B_{H}}-1\right)^{2}$, 
where $B_{H}$ denotes the households' steady-state holdings of government debt. We set $\phi_{B H}=0.20$, an adjustment cost higher than for deposits, capturing the idea that deposits are somewhat easier to adjust than bonds. In the bank problem, the adjustment cost takes the same form: the two parameters measuring the convexity of the adjustment cost function, $\phi_{B B}$ and $\phi_{B F}$, denote how costly it is for the banks to adjust domestic and foreign bonds: we set $\phi_{B B}=0.20$ and $\phi_{B F}=0.20$, implying equal adjustment costs for government bonds held by domestic banks, foreign banks, and households. As shown in the next section, assuming equal adjustment costs implies that all holders of sovereign bonds reduce their holdings by similar proportions in response to a tightening of the debt limit of the government. We choose this calibration as the benchmark in order to balance two opposing considerations. On the one hand, local banks may face smaller diseconomies of scale in liquidating domestic assets in a short period of time, so that they may adjust their domestic portfolio more quickly than their foreign counterparts (and reduce holdings of government debt by a relatively large amount following sovereign default). ${ }^{23}$ On the other hand, the recent experience of Ireland, Italy, Portugal, and Spain, where non-domestic holdings of government securities have declined substantially between 2009 and 2012, ${ }^{24}$ hints at the possibility that foreign lending might fall more than domestic lending should default occur in one of these countries. In the next section, we perform robustness analysis around these parameters.

Banks also pay a cost for adjusting deposits and loans. The cost functions are $\phi_{D B}\left(\frac{D_{t}}{D_{t-1}}-1\right)^{2}$ for deposits, and $\phi_{L B}\left(\frac{L_{t}}{L_{t-1}}-1\right)^{2}$ for loans. We set $\phi_{D B}=\phi_{L B}=0.05$. Portfolio adjustment costs capture transaction and trading costs associated with buying and selling financial assets. These costs are frequently assumed in the literature and are reputed to be important for explaining sluggish portfolio adjustment and limited participation to financial markets (see, e.g., Cooley and Quadrini, 1999, for a discussion).

To apportion the steady-state holdings of government debt to households, Periphery banks, and Core banks, we use several data sources on debt holdings of the Periphery. The key numbers are reported in Table 1 and refer to end of 2010. We begin with debt held by Core banks: data

\footnotetext{
${ }^{23}$ See Iacoviello and Minetti (2006) for a similar idea and related discussion.

${ }^{24}$ See for instance our Figure 1 as well as the note by J.P.Morgan (2012): "A primer on Euro area government debt markets". However, while private foreign lending seems to fall in the wake of foreign default, other studies (for instance Mendoza and Yue, 2012) find that foreign lending inclusive of official holdings tends to rise after default.
} 
on government debt held by foreign counterparties ${ }^{25}$ show that 49.7 percent of the Periphery debt is held outside the Periphery (either by European or by non-European financial institutions). Absent a country-by-country breakdown, we apportion this 49.7 percent to European and non-European financial institutions using the Consolidated Banking Statistics of the BIS, which show that 84 percent of the Periphery sovereign debt held by banks is held by European (Core) banks. ${ }^{26}$ Accordingly, we fix at 41.7 percent (that is, 84 percent times 49.7 percent) the share of public debt of the Periphery held by the Core bloc.

Next, we compute debt held by Periphery households. Using data from national flow of funds accounts, we estimate that 10.8 percent of government debt is held directly by local households. We increment this percentage by the holdings of non-European financial institutions, which equal 8 percent of the total debt of the Periphery, so that the share of public debt of the Periphery held by Periphery households is 18.8 percent in our calibration. The remainder of the Periphery government debt, 39.5 percent, is allocated to Periphery banks.

The calibration of the households' holding of government debt for the Core European bloc is based on national flow of funds accounts for France, Germany, Switzerland, and the United Kingdom. 11 percent of their collective sovereign debt is held by households in those countries. ${ }^{27}$ To ensure balanced trade in steady state, we force the foreign debt of the Core countries held by Periphery banks to match the level of its counterpart. The remainder of the outstanding debt of the Periphery European bloc, 70 percent of the total, is assigned to domestic banks.

For the parameters governing bank leverage, we set $\gamma_{L}=0.86$. Given the relative shares of loans and bonds in the bank balance sheet, this parameter implies a steady state bank capital to asset ratio of 0.10 (see for instance ECB, 2010).

Moving to the solution method, we use a piece-wise linear solution approach as is common in the expanding literature on the zero lower bound on nominal interest rates. ${ }^{28}$ We treat the possibility of default as an alternative regime. The same numerical method can handle occasionally binding

\footnotetext{
${ }^{25}$ These data are from the World Bank Quarterly External Debt Statistics.

${ }^{26}$ For the European bloc, we selected the banks of all the countries in the euro area (excluding Periphery) that respond to the BIS. The list of these countries included: Belgium, France, Germany, Switzerland, and the United Kingdom. The non-european bloc included all other countries in the BIS database (not including the Periphery).

${ }^{27}$ For both the Periphery and the Core, when national flow of funds data did not split out explicitly the holdings of government debt held by households, we used broader holdings of securities excluding shares.

${ }^{28}$ For instance, see Eggertson and Woodford (2003) and Bodenstein, Guerrieri and Gust (2010).
} 
constraints or regime switches that depend on the evolution of endogenous variables. In case of no default, the linearized system of necessary conditions for an equilibrium can be expressed as

$$
\mathcal{A}_{1} E_{t} X_{t+1}+\mathcal{A}_{0} X_{t}+\mathcal{A}_{-1} X_{t-1}=0
$$

where $\mathcal{A}_{1}, \mathcal{A}_{0}$, and $\mathcal{A}_{-1}$ are square matrices of coefficients, conformable with the vector $X$. In turn, $X$ is a vector of all the variables in the model expressed in deviation from the steady state for the regime without default. Similarly, in case of default, the linearized system can be expressed as

$$
\mathcal{A}_{1}^{*} E_{t} X_{t+1}+\mathcal{A}_{0}^{*} X_{t}+\mathcal{A}_{-1}^{*} X_{t-1}+\mathcal{C}^{*}=0
$$

where $\mathcal{C}^{*}$ is a vector of constants. In the absence of default, we use standard linear solution methods to express the decision rule for the model as

$$
X_{t}=\mathcal{P} X_{t-1}
$$

With default, we use a guess-and-verify approach. We shoot back towards the initial conditions, from the first period when no default is guessed. For example, to check for no default in period $t+1$ and default in period $t$, the decision rule between period $t-1$ and $t$ can be expressed as:

$$
\begin{gathered}
\mathcal{A}_{1}^{*} \mathcal{P} X_{t}+\mathcal{A}_{0}^{*} X_{t}+\mathcal{A}_{-1}^{*} X_{t-1}+\mathcal{C}^{*}=0 \\
X_{t}=-\left(\mathcal{A}_{1}^{*} \mathcal{P}+\mathcal{A}_{0}^{*}\right)^{-1}\left(\mathcal{A}_{-1}^{*} X_{t-1}+\mathcal{C}^{*}\right) .
\end{gathered}
$$

We proceed in a similar fashion to construct the time-varying decision rules for the case when default is guessed to last multiple periods or to happen starting in periods beyond $t$.

Under this solution, government bond yields reflect the possibility of default only when default is perfectly anticipated. Since anticipated future defaults imply a default premium that completely compensates bond holders for default, we conjecture and verify that default is only chosen for one period in response to contractionary unanticipated shocks. Intuitively, if anticipated, default will be priced into bond yields and the government will not find it convenient to default.

\section{$5 \quad$ Results}

We are interested in investigating the impact of unexpected shocks that induce partial default by the government of the Periphery. Our objective is to address the following questions: how do shocks to 
a government's debt service capacity propagate internationally? To what extent can they trigger a global credit crunch? And what are the factors that shape banks' responses to the government default shock, especially the relative contractions of loans and government bond holdings? To answer these questions, in this section we report the impulse responses of our model economy to country-specific shocks to productivity. To establish a benchmark, we first consider a scenario in which the shock is sufficiently small so that the government does not default on its debt obligations. Then, we turn to the scenario in which the shock is large enough that the government defaults.

\subsection{No Default}

To isolate the transmission of country-specific productivity shocks, we first consider the effects of a 1 percent decrease in the process $A_{t}$ in the Periphery. The autoregressive persistence is set to 0.95 .

As households anticipate a future rebound in output, consumption drops less than output up front, reflecting households' incentive to smooth consumption in response to the shock. Accordingly, the supply of households' savings contracts. Households' deposits and holdings of bonds fall by roughly similar amounts.

To understand the response of equilibrium bond rates, one must also take into account the government supply of bonds. Under the benchmark calibration, the debt ceiling is sufficiently elastic with respect to output that the drop in supply exceeds the drop in savings at constant interest rates. Therefore, to reduce demand for bonds and reestablish the equilibrium in the bonds market, the yield on public debt falls. Lower interest rates on bonds lead banks to skew their portfolio towards loans to entrepreneurs, cushioning the drop in investment in the Periphery and leading to an expansion in investment abroad. In this respect, the implications for the spillover effects of country-specific shocks in our baseline model with no default are closely aligned with those that obtain in an international real business cycle model with complete markets, in which resource reallocation implies that shocks in one country do not generate international comovement. We therefore consider in the next subsection whether or not introducing default can generate output comovement across countries.

\subsection{Default}

We now turn to the scenario where government default occurs. Figure 3 shows the effects of a 5 percent decline in technology. The solid lines show the piece-wise linear solution that reflects the partial default 
on government debt in the Periphery. The dashed lines show the response in a model that excludes the possibility of default, but is otherwise identical to the benchmark.

The amount of default is governed by the parameter $\zeta$ in the budget constraint of the government. We choose $\zeta$ to mimic a scenario somewhat worse than the March 2012 Greek debt restructuring, when the face value of Greek sovereign debt held by private investors was cut by about 100 billion euros. Given our calibration, such a scenario would correspond to a (partial) default equal to roughly 4 percent of the annual GDP of Greece, Italy, Portugal and Spain, our periphery bloc, and, taking into account country sizes, 1.5 percent of the GDP for the Core. In our experiment, we size $\zeta$ so that the non-repayment is equal to 10 percent of GDP in the Periphery. As a consequence the losses for Core banks amount to about 1.25 percent of Core GDP. Ultimately, the main impact of the default on core European economies is to erode bank capital by about 80 billion euros.

As shown in Figure 3, sovereign default initially cushions the contraction in government spending in the periphery - in the first period, the black line in panel 3 is above the dashed line. Mechanically, the punishment for default is in the form of a fixed proportional reduction in the debt ceiling. Default occurs because the contraction in output lowers the debt ceiling even in the absence of default. Accordingly, as the economy contracts, the punishment shrinks in absolute terms and default implies a rise in government spending on the margin.

As the punishment is persistent, and the debt ceiling is lag dependent, government debt initially continues to shrink. Then, as output gradually recovers, the government ability to borrow also bounces back. In spite of a reduced ability to borrow, lower interest payments eventually allow government spending to expand above the steady state level.

The evolution of investment and capital in the Periphery is closely linked to the behavior of loan rates. In turn, loan rates are influenced by two opposing effects, a portfolio substitution effect and a hit to the equity position of banks stemming from the default. To explain the portfolio substitution effect, it is helpful to consider sovereign bond rates. As seen above, even without default, a negative productivity shock lowers the returns on government bonds, because the supply of bonds falls more than the demand. Furthermore, in our setting, no further default is anticipated for the future. By curtailing the government's ability to issue debt, the punishment from default deepens the initial drop in bond yields. Due to lower yields, Periphery banks find it optimal to substitute away from government bonds into loans to entrepreneurs. The equity effect stems from banks' direct losses when the default 
rate rises above what expected when they invested in bonds. This loss induces a decline in banks' capitalization and in turn, in the presence of binding capital requirements, generates a contraction in credit supply. Overall, the equity effect dominates. Accordingly loan rates rise on the margin and capital and investment fall below the level that would have prevailed in the absence of default.

Similar considerations apply to loan rates in the Core. The capitalization of Core banks shrinks. However, as Periphery sovereign debt accounts for a smaller fraction of the portfolio of Core banks, the direct hit from default on their equity position is smaller. Faced with the need to restore their target position for government debt, Core banks divert part of their funds away from lending to entrepreneurs. Accordingly, Core loan rates (not plotted) rise and, returning to Figure 3, entrepreneurs' investment and capital contract. Hence, the overall spillover effects of sovereign default on foreign output are negative. In our benchmark calibration, output drops nearly 0.4 percent relative to no-default case when default occurs.

As the large productivity shock pushes output in the Periphery bloc down, the resource constraint implies that the expansions in investment and government spending described above need to be counterbalanced by a contraction in absorption elsewhere. Panel 4 of Figure 3 shows that the default pushes down Core consumption. Furthermore the bottom panel of Figure 4 shows that the counterpart to the debt repudiation is a contraction (after a short-lived increase) in Periphery net exports.

\subsection{Decomposing the Marginal Effects of Default into Debt Repudiation and Pun- ishment}

How large and persistent are the effects of a government default shock and their international spillovers? Figure 5 presents the marginal effects of default. The solid lines in that figure are the difference between the 5 percent productivity contraction in the Periphery bloc with and without default - respectively the solid and dashed lines in Figure 3. As shown in Figure 5, after controlling for the decline in output that would happen under no default, both Core and Periphery output contract after default. In the baseline calibration, they are almost 0.5 percent below baseline after two years.

Figure 5 also presents a decomposition of the marginal effects of default into two components. One component is the debt repudiation effect, the other component is the punishment effect, that is, the marginal effect of the reduction in the debt ceiling. ${ }^{29}$

\footnotetext{
${ }^{29}$ The marginal effect of debt repudiation (without punishment) is computed as the difference between the responses
} 
In our model, the punishment scheme ensures that defaults are rare events, associated with large declines in output. An alternative way of reconciling this observation is to rely on a punishment scheme that involves a utility loss for the government when default occurs. Under such a scheme, the marginal effects of default would then be limited to marginal effects of the debt repudiation, the dashed lines in Figure 5.

The marginal effects of debt repudiation imply a fall in output both in the Periphery and Core blocs. There are three main channels that explain the relative size of the output loss in the two blocs: a hit to Periphery household wealth, a hit to the equity position of banks, and portfolio rebalancing.

With multiple agents holding Periphery sovereign debt, sizing the hit to the wealth of Periphery households depends importantly on the government spending rule and on the tax rate reaction function. With taxes largely unchanged, as implied by the tax rate reaction function in Equation (12), and with an expanding level of government spending, the wealth effect of default on Periphery households is negative - the interest payments that would have gone to households are now used to push up government spending. The hit to wealth lowers the consumption of Periphery households. However, consumption smoothing motives induce Periphery households to spread the fall in consumption through time. Savings decline and bank deposits are reduced. In turn, lower deposits coupled with binding capital requirements for banks, reduce the supply of loans and bring investment down.

The debt repudiation has another important effect. It erodes the equity positions of Periphery and Core banks. Lending declines, capital stocks shrink. With the decline in capital, hours worked go down, both because there is a contraction in labor demand, and because the real wage declines.

In sum, debt repudiation pushes consumption, investment, and output down in both the Periphery and Core blocs. The effects on output in the Periphery are slightly larger, even accounting for relative sizes, because of the additional negative wealth effect on Periphery households.

Figure 5 also shows that the reduction in the debt ceiling buffets the increase in Periphery government spending, keeps down lending rates (at least on impact) and allows Periphery investment and consumption (at least eventually) to expand on the margin. The dotted lines shown in the figure, have an interpretation that goes beyond the decomposition presented. They can also be interpreted as the responses to a shock that lowers the debt ceiling of the Periphery government. The shock is governed by the lower branch of Equation 14 and the innovation to the process (not shown in the to a 5 percent productivity shock with and without default in a model in which $\underline{b}=\bar{b}$ 
equation) would be sized to 9.6 percent of Periphery steady-state output.

\subsection{Sensitivity Analysis}

Figures 6, 7, and 8 present sensitivity analysis. For ease of comparison, in those three figures, the solid lines report again the marginal effects of default under the benchmark calibration, as presented in Figure 5. The broken lines show the marginal effects of default under alternative calibrations.

Our first sensitivity experiment consists of modifying the degree of international integration of bond markets, i.e., the financial openness of the two countries. Figure 6 considers an alternative calibration that implies financial autarky, that is, banks do not hold foreign government bonds. We achieve autarky by reassigning the Periphery debt held in the Core bloc to Periphery banks and pushing up the adjustment costs on foreign debt - we set $\phi_{B F}=100$. Imposing financial autarky effectively shuts down the international transmission of shocks through the financial sector. As the figure shows, compared to the baseline calibration, the spillover effects of default from the Periphery to the Core bloc fades away. Accordingly, the response of output in the periphery (panel 7) is essentially flat. These results confirm the centrality of financial integration through the banking sector in accounting for the sizable spillover effects of sovereign default.

Figure 7 considers two alternative calibrations for the portfolio adjustment costs on the holdings of sovereign bonds. Under our benchmark calibration, the parameters governing the adjustment cost are the same for domestic and foreign holders $\left(\phi_{B B}=0.2, \phi_{B H}=0.2\right.$, and $\left.\phi_{B F}=0.2\right)$. The dashed lines in the figure show the effects of imposing a lower adjustment cost for foreign than for domestic bonds, which could capture greater facility of foreign agents to reduce their bond holdings. In that case, we set $\phi_{B B}=0.50, \phi_{B H}=0.50$, and $\phi_{B F}=0.10$. Under this alternative, Periphery banks and households attempt to maintain their holdings of Periphery government bonds at the levels prevailing prior to default. By contrast Core banks shift away from lower-yielding government bonds of the Periphery. In the Core, this portfolio reallocation frees up funds that can be redirected to lending: loan rates fall and investment, capital, and output expand. By contrast, the implied output costs of default in the Periphery are much larger. Output falls as much as 1.5 percent below baseline after two years.

Figure 7 also considers an alternative calibration that makes the adjustment costs on the holdings of sovereign bonds smaller for domestic holders than for foreign, which could capture greater facility of 
domestic agents to reduce their bond holdings. Under that calibration, we set $\phi_{B B}=0.10, \phi_{B H}=0.10$, and $\phi_{B F}=0.50$. The results for this alternative are shown by the dotted lines. This configuration of adjustment costs generates a beggar-thy-neighbor effect of sovereign default: as Core banks try to restore their pre-default holdings of government debt, they reduce lending in their own economy, thus exacerbating the decline in output in the Core, while boosting the recovery in the Periphery.

Figure 8 presents sensitivity analysis relative to the choice of preferences. The alternative considered for the period utility function is a familiar specification which is additively separable in consumption and labor supply and follows the general form spelled out in King, Plosser, and Rebelo (1988):

$$
u=\log C_{H, t}-\frac{N_{H, t}^{1+\eta}}{1+\eta} .
$$

The benchmark preferences exclude a wealth effect on labor supply. By contrast, the alternative preferences in Figure 8, allow for wealth effects to influence labor supply. When wealth declines, labor supply expands. Under this alternative preference specification, an expansion in labor supply buffets the contraction in output both in the Periphery and Core blocs. While this alternative is not implausible, in a model like ours that excludes labor market frictions, we prefer the benchmark specification that links hours worked more closely to supply factors.

\section{Conclusions}

This paper has investigated the international transmission of government default shocks through the

banking system. We have considered a two-country model where banks grant loans and invest in government bonds both domestically and abroad.

Our results reveal that sovereign default generates output comovement across countries. In our benchmark experiment, a sovereign default of 10 percent of Periphery GDP reduces GDP in the Core and the Periphery by almost half a percent after two years. Larger default amounts could cause even larger declines in economic activity. For instance, given a rough linearity of the effects, a default equal to 30 percent of Periphery GDP could induce a 1.5 percent decline in the GDP in Europe. We believe that these estimates are conservative: for instance, our model lacks nominal rigidities, and confidence channels that could make the spillovers even larger.

A key advantage of our analysis is that we can parse cause and effect, which allows us to isolate 
the marginal contribution of default over and above the effects of a large recession. Achieving this feat is much harder with direct empirical analysis.

The emphasis of the analysis has been on the solvency of governments and its impact on the credit market in the presence of tight bank capital requirements. However, the increase in the sovereign default risk of periphery countries has also turned into a major liquidity crisis in the European interbank market. As a result of the increase in the riskiness of their portfolios, the banks of core European countries have experienced a liquidity "freeze" in the interbank market.

A pressing step for future research is to embed an interbank market into our environment and allow for the presence of a lender of last resort. Such an analysis would help shed light on the way the interventions of central banks can shape the transmission of a credit crunch induced by a sovereign debt crisis, for example by affecting banks' asset portfolio choices. During the current crisis, for instance, after engaging initially in purchases of sovereign bonds in the secondary market, the European Central Bank has shifted to a policy of liquidity provision to banks. It has granted large amounts of loans to banks, accepting government bonds as collateral, including bonds of governments at higher risk of default. As a result of these Long Term Refinancing Operations, banks have allegedly tilted their portfolios towards government bonds. These operations have alleviated the funding pressures for governments, but it is hard to size their effects on the funding costs for firms. We leave the analysis of this and other issues for future research. 


\section{References}

[1] Backus, D. K., P. J. Kehoe, and F.E. Kydland (1992) "International real business cycles," Journal of Political Economy 100, 745-775.

[2] Baxter, M., and M. J. Crucini (1995) "Business cycles and the asset structure of foreign trade," International Economic Review 36, 821-854.

[3] Bernanke, B. S., M. Gertler, and S. Gilchrist (1999) "The financial accelerator in a quantitative business cycle framework," in: J. B. Taylor \& M. Woodford, eds., Handbook of Macroeconomics 1, 1, pp. 1341-1393.

[4] Bodenstein, M., L. Guerrieri, and C. Gust (2010) "Oil shocks and the zero bound on nominal interest rates," Board of Governors of the Federal Reserve System, International Finance Discussion Papers, Number 1009.

[5] Christiano, L., R. Motto and M. Rostagno (2003) "The great depression and the FriedmanSchwartz hypothesis," Proceedings, Federal Reserve Bank of Cleveland, 1119-1215.

[6] Dedola, L. and G. Lombardo (2012) "Financial frictions, financial integration and the international propagation of shocks," Economic Policy 70, 319-359.

[7] Den Haan, W. J., G. Ramey, and J. Watson (2003) "Liquidity flows and fragility of business enterprises," Journal of Monetary Economics 50, 1215-1241.

[8] De Paoli, B., G. Hoggarth, and V. Saporta (2006) "Costs of sovereign default". Bank of England Financial Stability Paper. No. 1.

[9] Devereux, M. B. and A. Sutherland (2011) "Country portfolios in open economy macro-models," Journal of the European Economic Association 9, 337-369.

[10] Devereux, M. B. and J. Yetman (2010) "Leverage constraints and the international transmission of shocks," Journal of Money, Credit and Banking 42 (s1), 71-105.

[11] Eaton, J., and M. Gersovitz (1981) "Debt with potential repudiation: Theoretical and empirical analysis," Review of Economic Studies 48, 289-309. 
[12] ECB (2010). Financial stability review (June 2010), European Central Bank.

[13] Eggertsson, G., and M. Woodford (2003) "The zero bound on interest rates and optimal monetary policy," Brookings Papers on Economic Activity 34, 139-235.

[14] Gerali, A., S. Neri, L. Sessa, and F. M. Signoretti (2010) "Credit and banking in a dsge model of the euro area," Journal of Money, Credit and Banking 42 (s1), 107-141.

[15] Gertler, M. and P. Karadi (2011) "A model of unconventional monetary policy," Journal of Monetary Economics 58, 17-34.

[16] Gertler, M. and N. Kiyotaki (2010) "Financial intermediation and credit policy in business cycle analysis," in: B. M. Friedman and M. Woodford, eds., Handbook of Monetary Economics 1, 3, pp. 547-599.

[17] Gilchrist, S. (2004) "Financial markets and financial leverage in a two-country world economy," Central Banking, Analysis, and Economic Policies Book Series, in: L. A. Ahumada, J. R. Fuentes, N. Loayza and K. Schmidt-Hebbel, eds., Banking market structure and monetary policy 1, 7, pp. 27-58, Central Bank of Chile.

[18] Gilchrist, S., J. O. Hairault, and H. Kempf (2002) "Monetary policy and the financial accelerator in a monetary union," European Central Bank w.p. 175.

[19] Goodfriend, M., and B.McCallum (2007) "Banking and interest rates in monetary policy analysis: A quantitative exploration," Journal of Monetary Economics, 54, 1480-1507.

[20] Greenwood, J., Z. Hercowitz, and G. W. Huffman (1988) "Investment, capacity utilization, and the real business cycle," American Economic Review, 78, 402-17.

[21] Grilli, V., D. Masciandaro, and G. Tabellini (1991) "Political and monetary institutions and public financial policies in the industrial countries," Economic Policy, 6, 2, 341-392.

[22] Grossman, H. I., and J. B. Van Huyck (1988) "Sovereign debt as a contingent claim: Excusable, default, repudiation, and reputation," American Economic Review, 78, 5, 1088-1097.

[23] Hartley, P. (1998) "Inside money as a source of investment finance”, Journal of Money, Credit and Banking, 30, 2, 193-217. 
[24] Hartley, P., and C. Walsh (1991) "Inside money and monetary neutrality", Journal of Macroeconomics, 13, 3, 395-416.

[25] Heathcote, J., and F. Perri (2002) "Financial autarky and international business cycles," Journal of Monetary Economics 49, 601-627.

[26] Iacoviello, M. (2011) "Financial business cycles", Working Paper, Federal Reserve Board.

[27] Iacoviello, M., and R. Minetti (2006) "International business cycles with domestic and foreign lenders," Journal of Monetary Economics 53, 2267-2282.

[28] Kamber, G. and C. Thonissen (2012) "Financial intermediation and the international business cycle: The case of small countries with large banks," Working Paper, Reserve Bank of New Zealand.

[29] Kehoe, P. J., and F. Perri (2002) "International business cycles with endogenous incomplete markets," Econometrica 70, 907-928.

[30] Kalemli-Ozcan, S., E. Papaioannou, and F. Perri (2011) "Global banks and crisis transmission," Working paper, University of Houston.

[31] King, R.G., C.I. Plosser, and S.T. Rebelo (1988) "Production, growth and business cycles : I. The basic neoclassical model," Journal of Monetary Economics 21, 195-232.

[32] Kiyotaki, N., and J. Moore (1997) "Credit cycles," Journal of Political Economy 105, 211-248.

[33] Kollmann, R., Z. Enders, and G. Muller (2011) "Global banking and international business cycles," European Economic Review 55, 407-426.

[34] Levy Yeyati, E., and U. Panizza (2011). "The elusive costs of sovereign defaults," Journal of Development Economics, 94. 1, 95-105.

[35] Mendoza, E. and V. Quadrini (2010) "Financial globalization, financial crisis and contagion," Journal of Monetary Economics 57, 24-39.

[36] Mendoza, E. and V. Yue (2012). "A general equilibrium model of sovereign default and business cycles," Quarterly Journal of Economics, 127, 2, 889-946. 
[37] Minetti, R. (2007) "Bank capital, firm liquidity, and project quality," Journal of Monetary Economics 54, 2584-2594.

[38] Obstfeld, M., and K. Rogoff (1997), Foundations of International Macroeconomics, Cambridge, MA, MIT Press.

[39] Olivero, M. P. (2010) "Market power in banking, countercyclical margins and the international transmission of business cycles," Journal of International Economics 80, 292-301.

[40] Paasche, B. (2001) "Credit constraints and international financial crises," Journal of Monetary Economics 48, 623-650.

[41] Perri, F. and V. Quadrini (2011) "International recessions," NBER working paper 17201.

[42] Rieth, Malte (2011) "Myopic governments and welfare-enhancing debt limits," European Central Bank w.p. 1308.

[43] Shambaugh, J. C (2012) "The euro's three crises," Brookings Papers on Economic Activity, Brookings Institution, Washington D.C.

[44] Sturzenegger, F. (2004) "Toolkit for the analysis of debt problems,". Journal of Restructuring Finance 1 (1), 201-203.

[45] The Economist (2012) "Oat cuisine," February 11th.

[46] Ueda, K. (2012) "Banking globalization and international business cycles: Cross-border chained credit contracts and financial accelerators," Journal of International Economics 86, 1-16. 
Table 1: Sovereign Debt in the European Periphery (Greece, Italy, Portugal and Spain), broken down by holder (Periphery Households, Periphery Banks, Core Banks)

\begin{tabular}{|cl|c|c||c||c||c|}
\hline Country & & \multicolumn{5}{|c|}{ Holdings of Sovereign Debt, end-2010 } \\
\hline \multirow{2}{*}{ Italy } & Bn Euros & 184.3 & 149.1 & 649.2 & 555.5 & $1,538.2$ \\
& \% of GDP & 11.9 & 9.6 & 41.8 & 35.8 & 99 \\
& \% of Total & 12.0 & 9.7 & 42.2 & 36.1 & 100 \\
\hline \multirow{2}{*}{ Spain } & Bn Euros & 46.6 & 46.2 & 240.4 & 189.2 & 522.4 \\
& \% of GDP & 4.4 & 4.4 & 22.9 & 18.0 & 49.7 \\
& \% of Total & 8.9 & 8.8 & 46.0 & 36.2 & 100 \\
\hline Portugal & Bn Euros & 22.7 & 9.1 & 85.8 & 36.4 & 154.0 \\
& \% of GDP & 13.1 & 5.3 & 49.7 & 21.1 & 89.2 \\
& \% of Total & 14.7 & 5.9 & 55.7 & 23.7 & 100 \\
\hline \multirow{2}{*}{ Greece } & Bn of Euros & 19.9 & 9.3 & 169.7 & 129.8 & 328.6 \\
& \% of GDP & 8.6 & 4.0 & 73.7 & 56.4 & 142.8 \\
& \% of Total & 6.1 & 2.8 & 51.6 & 39.5 & 100 \\
\hline Pn of Euros & 273.5 & 204.2 & $1,059.8$ & $1,005.7$ & $2,543.2$ \\
& \% of GDP & 9.1 & 6.8 & 35.2 & 33.4 & 84.6 \\
& \% of Total & 10.8 & 8.0 & 41.7 & 39.5 & 100 \\
\hline
\end{tabular}


Figure 1: French Banks and Sovereign Debt of Greece, Italy, Portugal and Spain.

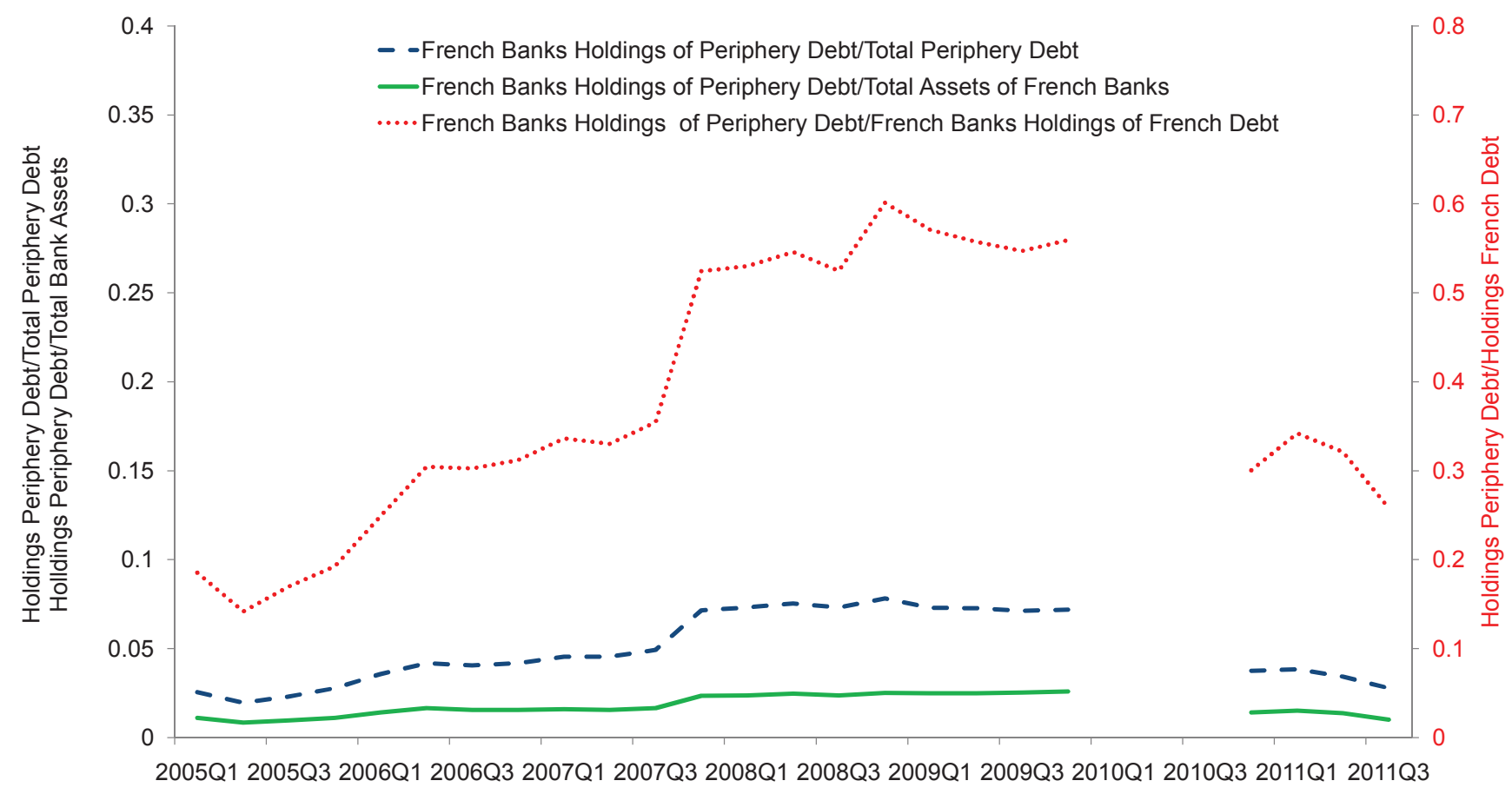


Figure 2: Decline in Productivity in the Periphery - No Default
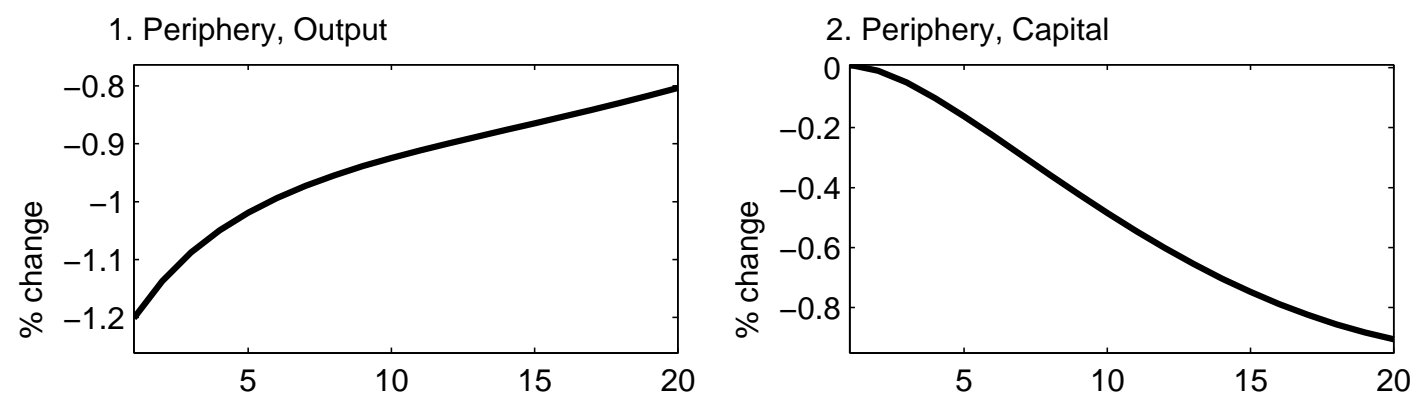

3. Periphery, Government Spending (share of SS output)

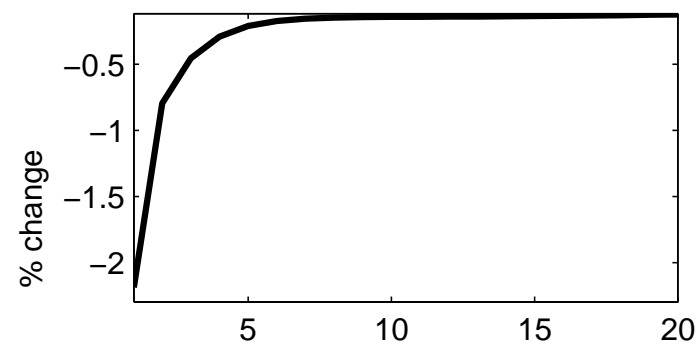

4. Periphery, Household Consumption

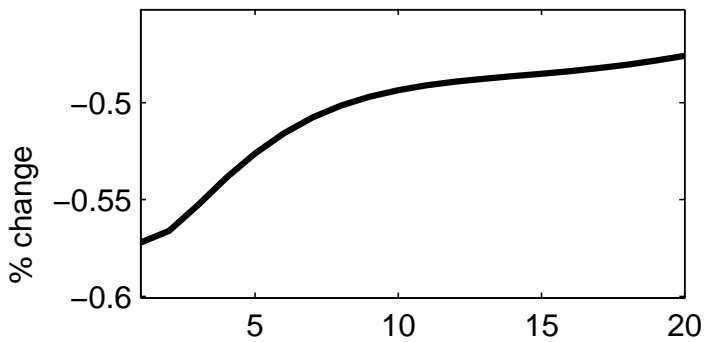

5. Periphery, Public Debt

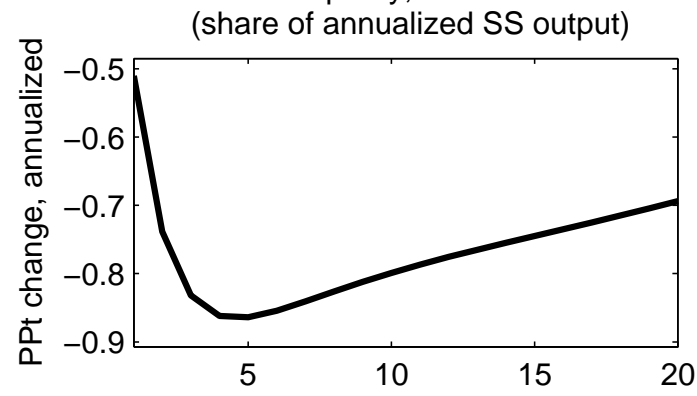

6. Periphery, Loan Rate (5-year)

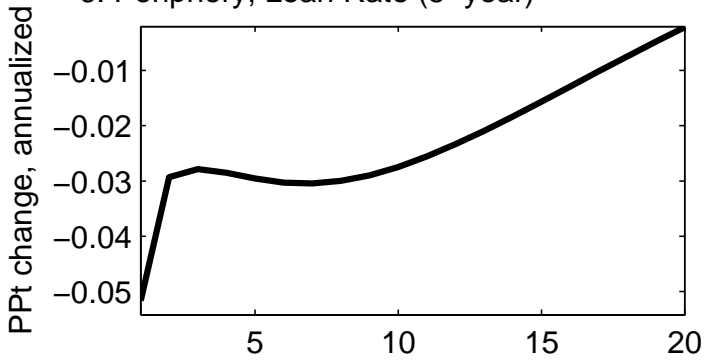

7. Core, Output

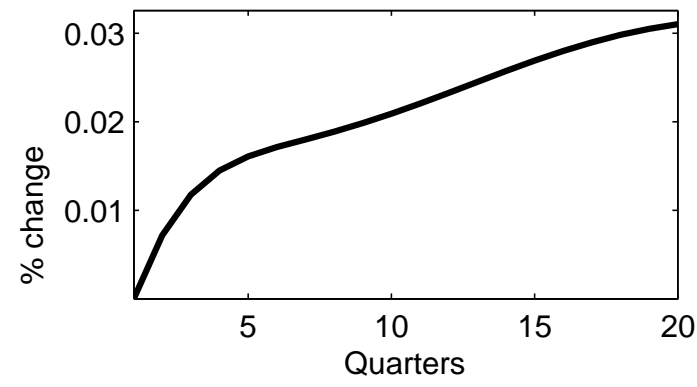

8. Core, Capital

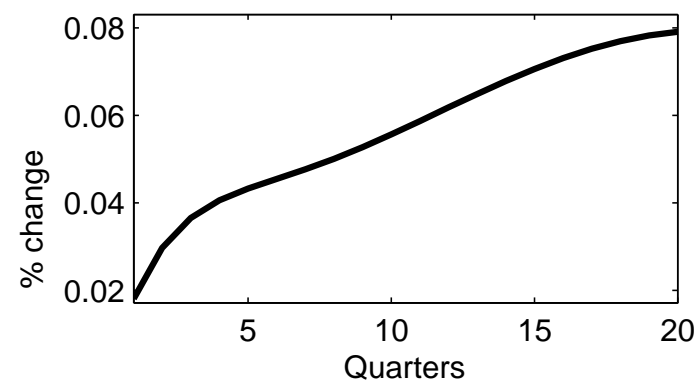


Figure 3: Decline in Productivity in the Periphery - Default
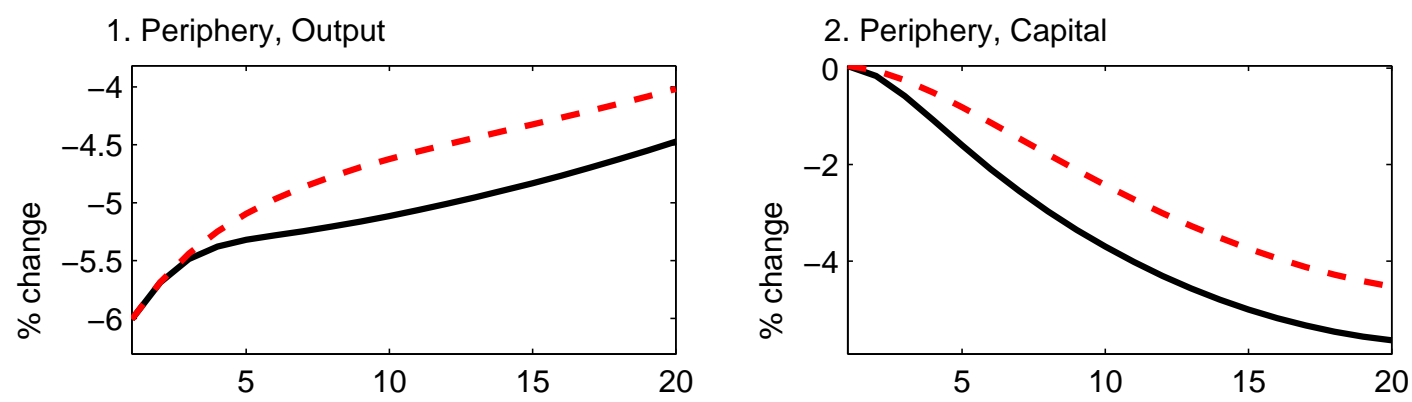

3. Periphery, Government Spending (share of SS output)
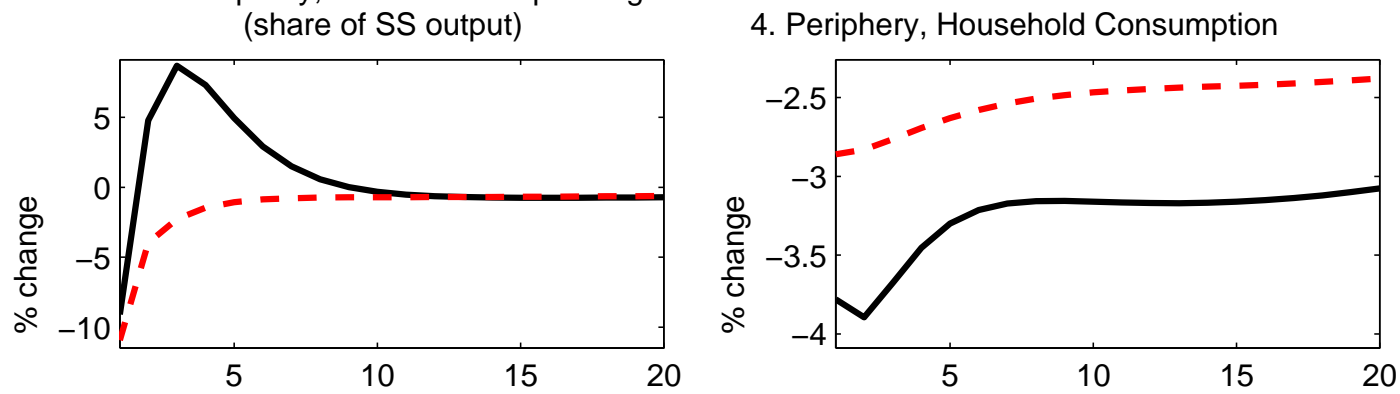

5. Periphery, Public Debt
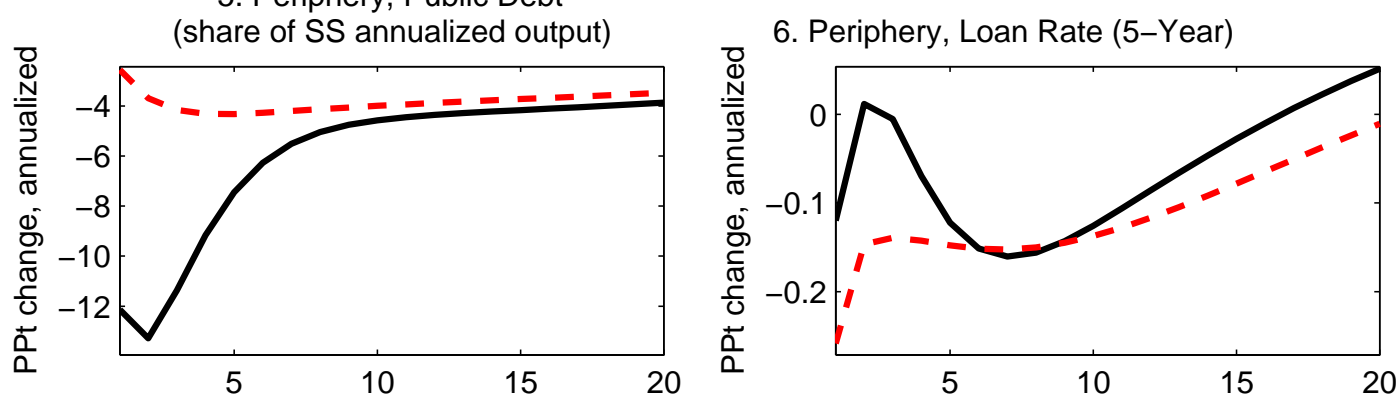

7. Core, Output

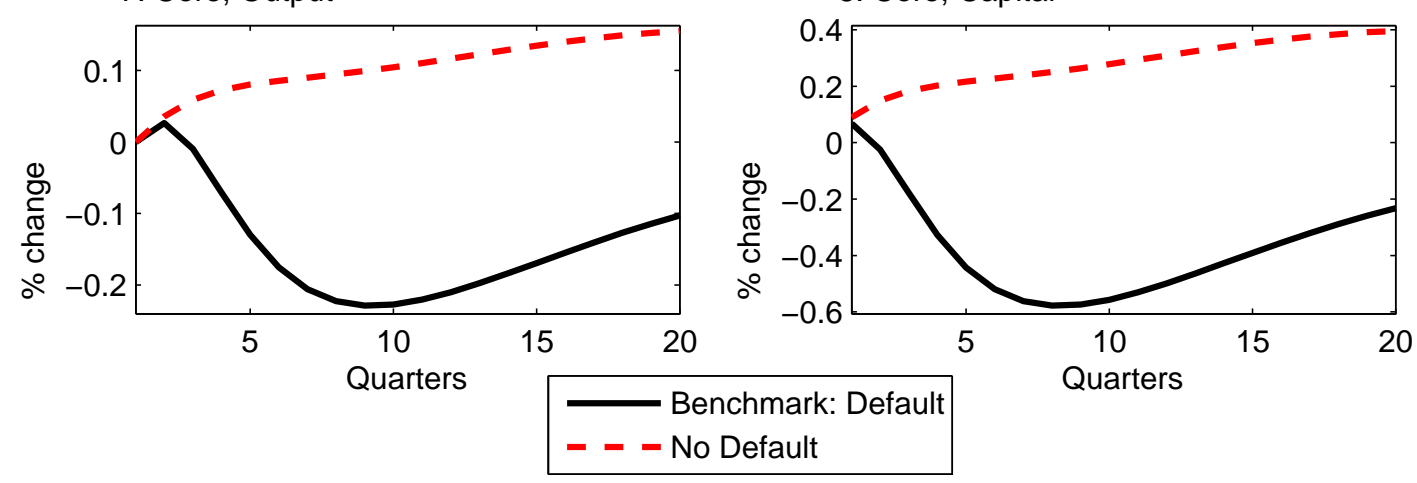


Figure 4: Decline in Productivity in the Periphery - Default

Periphery, Sovereign Borrowing (share of annualized output)
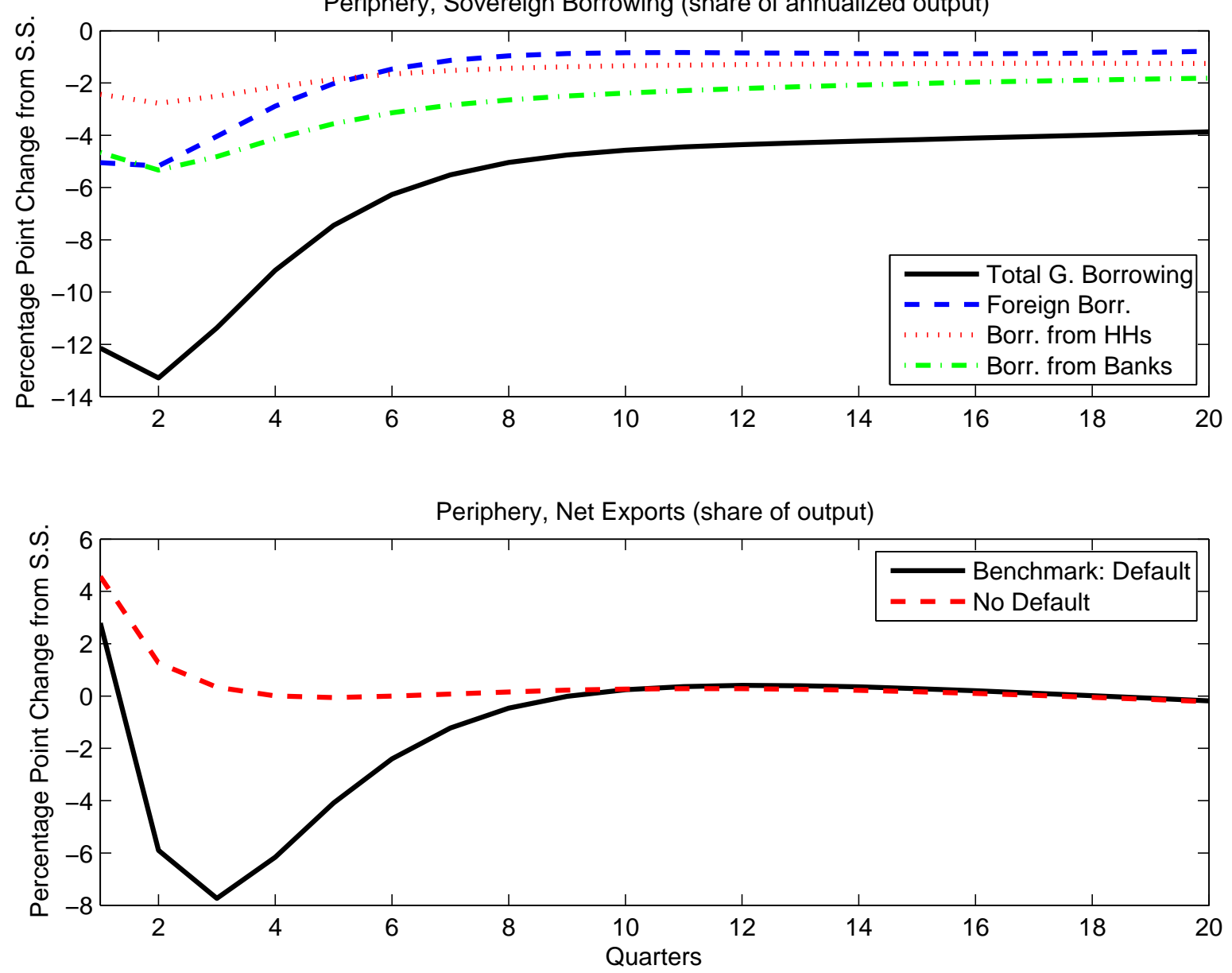
Figure 5: A Demposition of the Marginal Effects of Default in the Periphery
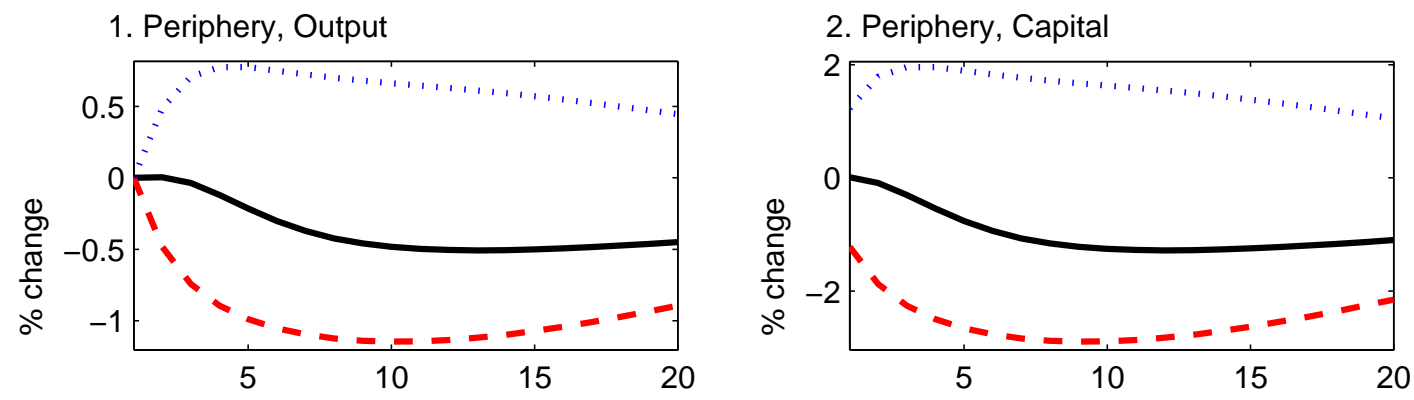

3. Periphery, Government Spending (share of SS output)

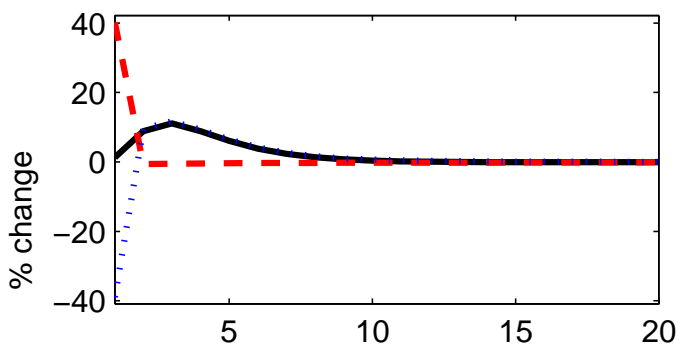

4. Periphery, Household Consumption

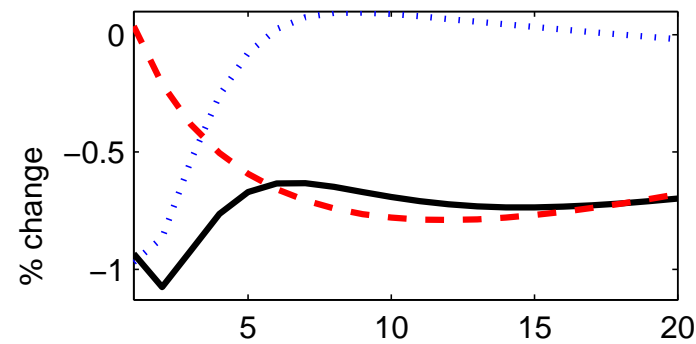

5. Periphery, Public Debt
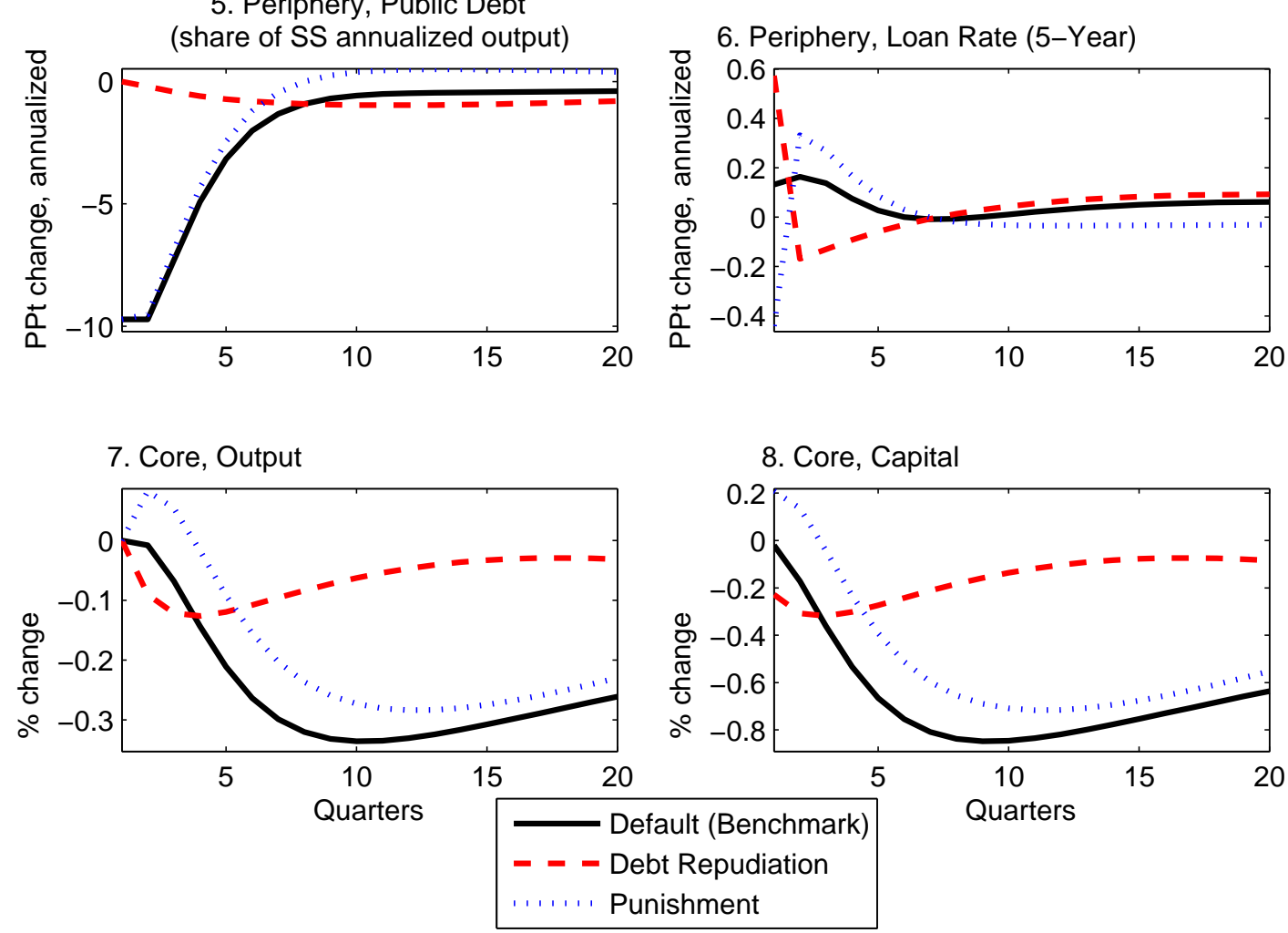
Figure 6: Marginal Effects of Default in the Periphery- No Foreign Debt
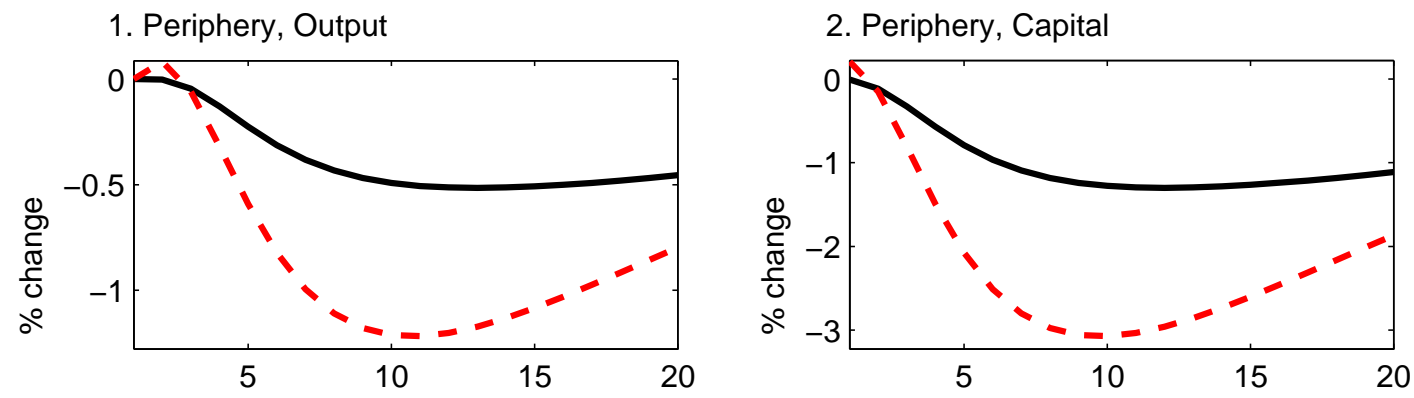

3. Periphery, Government Spending (share of SS output)
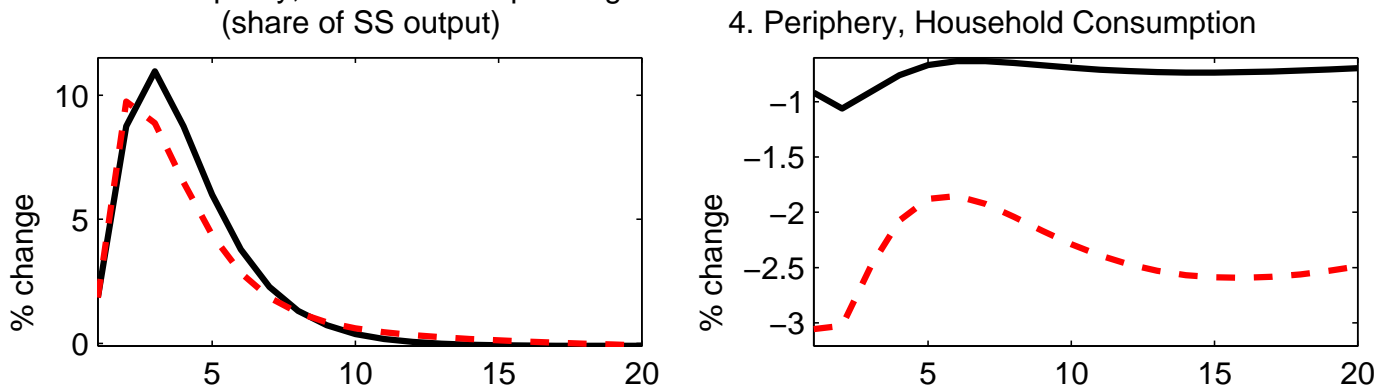

5. Periphery, Public Debt (share of SS annualized output)
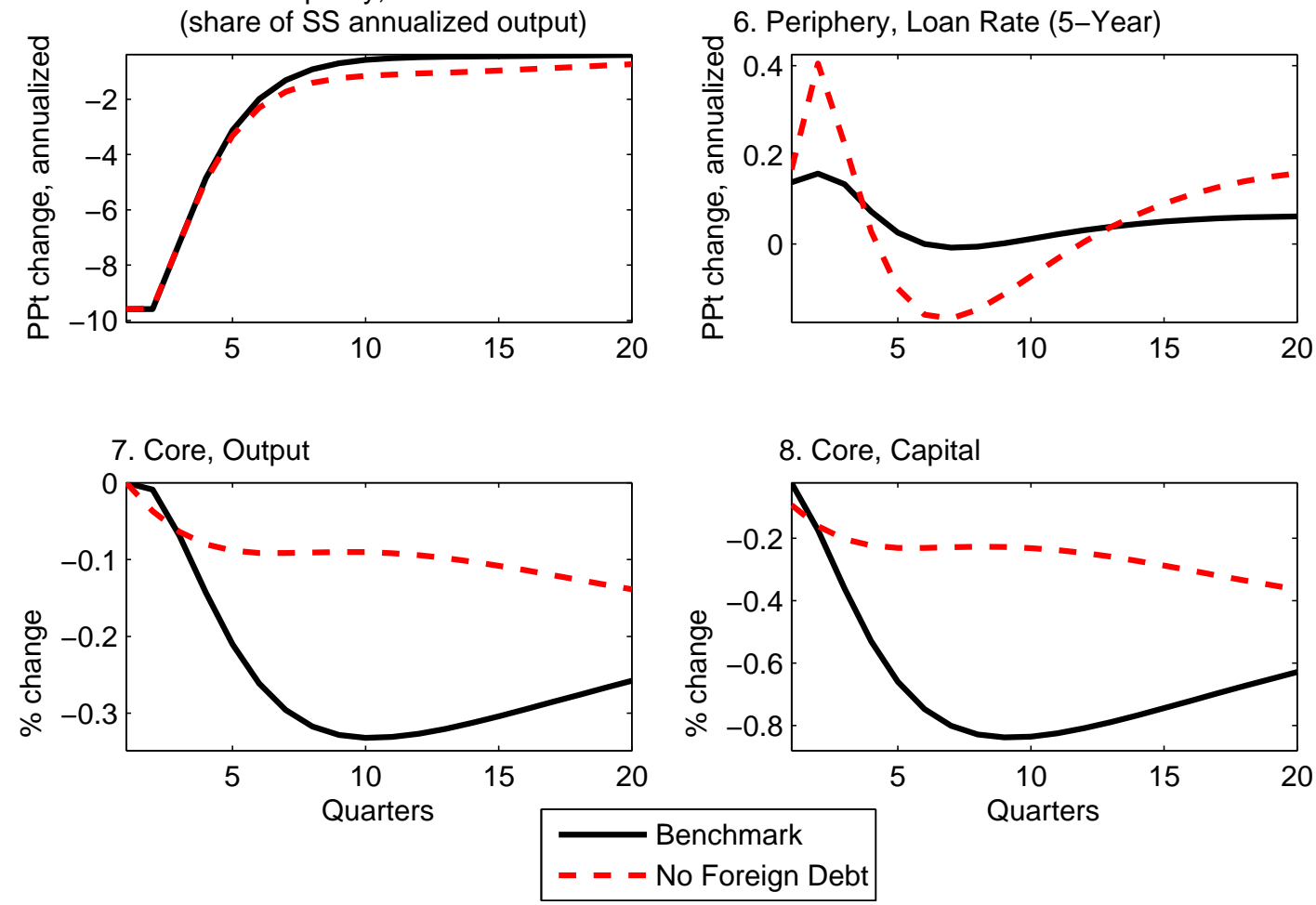
Figure 7: Marginal Effects of Default in the Periphery - Alternative Portfolio Adjustment Costs

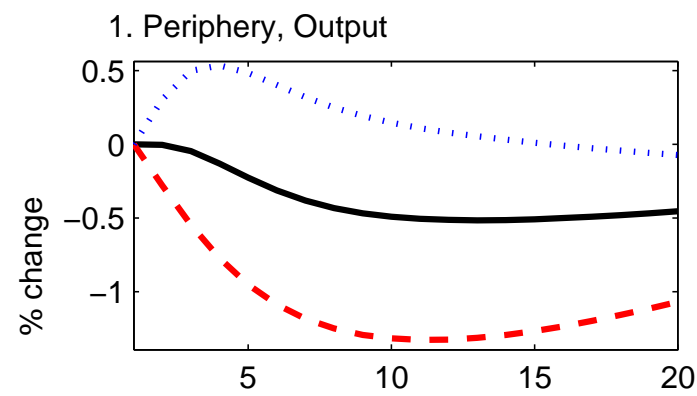

2. Periphery, Capital

3. Periphery, Government Spending (share of SS output)
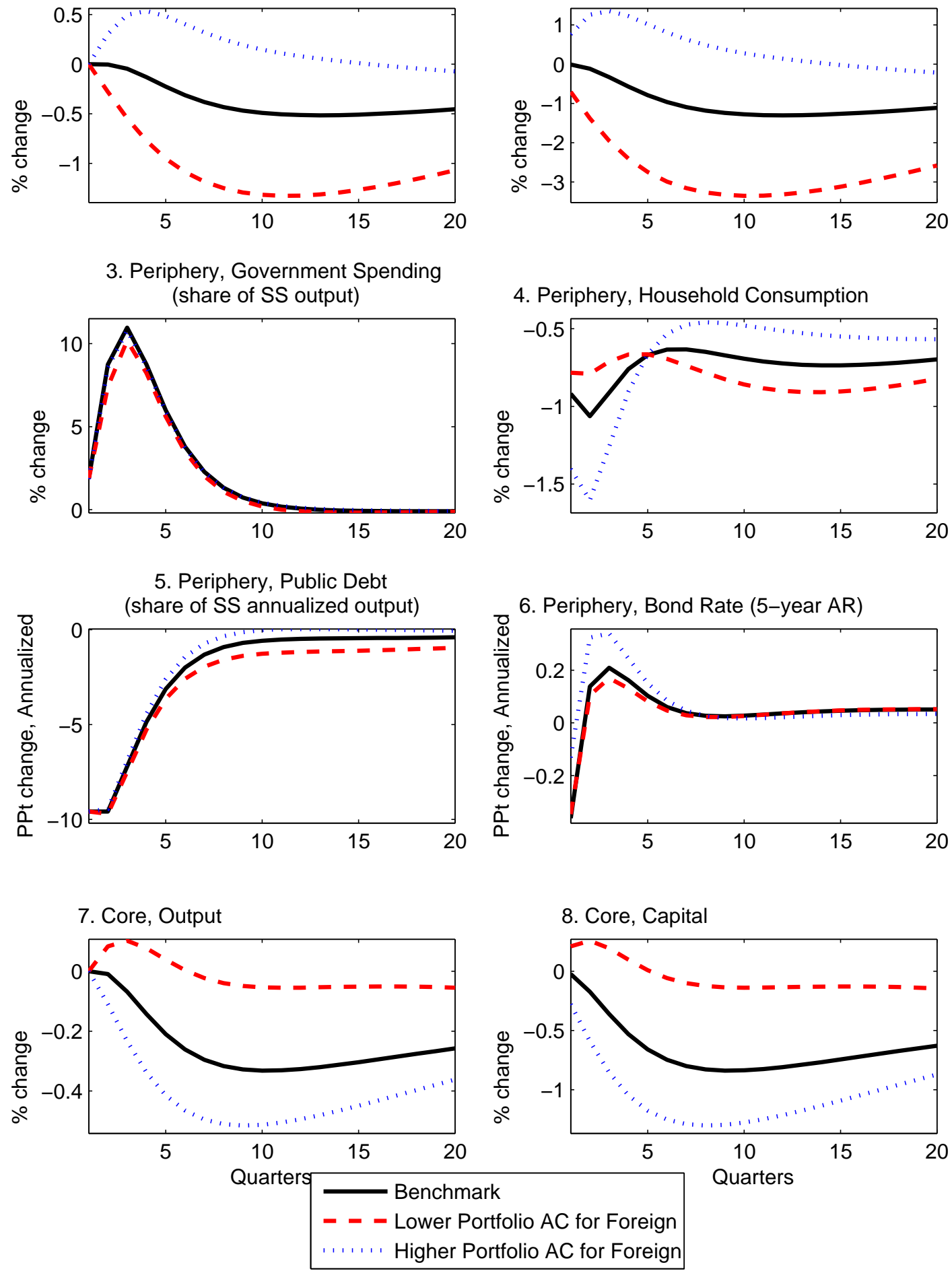
Figure 8: Marginal Effects of Default in the Periphery - King-Plosser-Rebelo Preferences
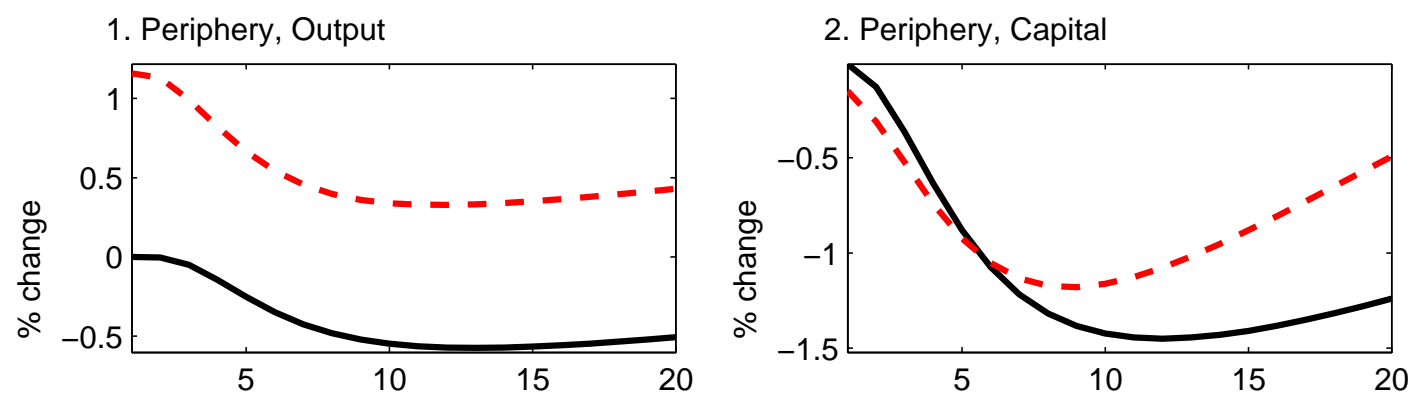

3. Periphery, Government Spending (share of SS output)

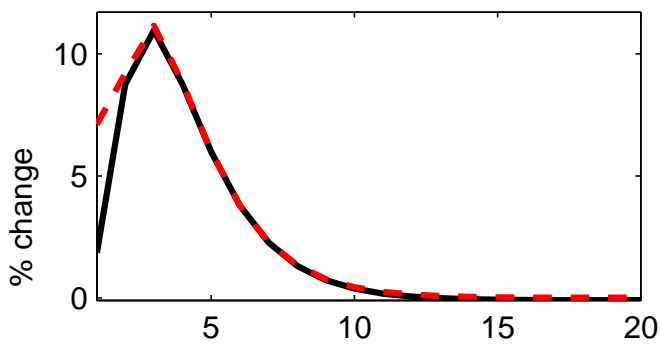

4. Periphery, Household Consumption

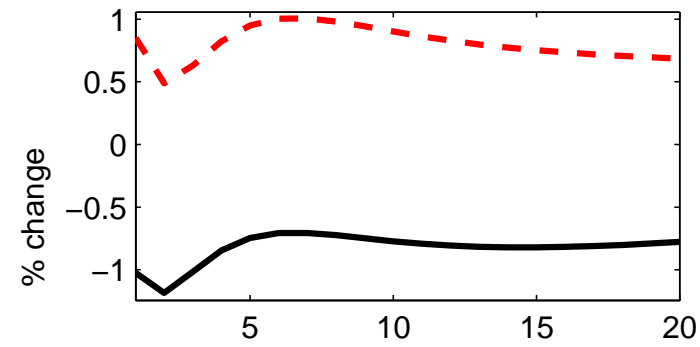

5. Periphery, Public Debt
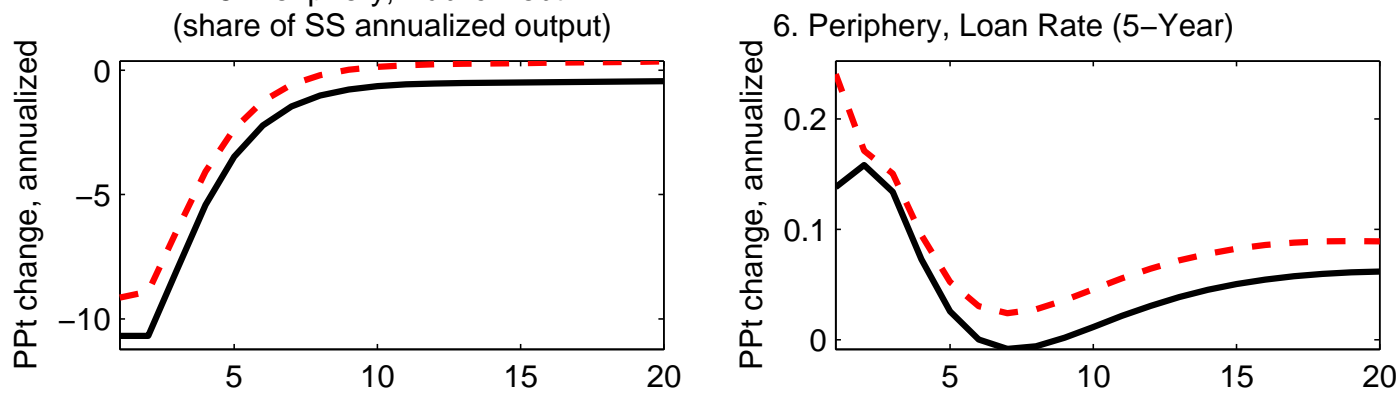

7. Core, Output

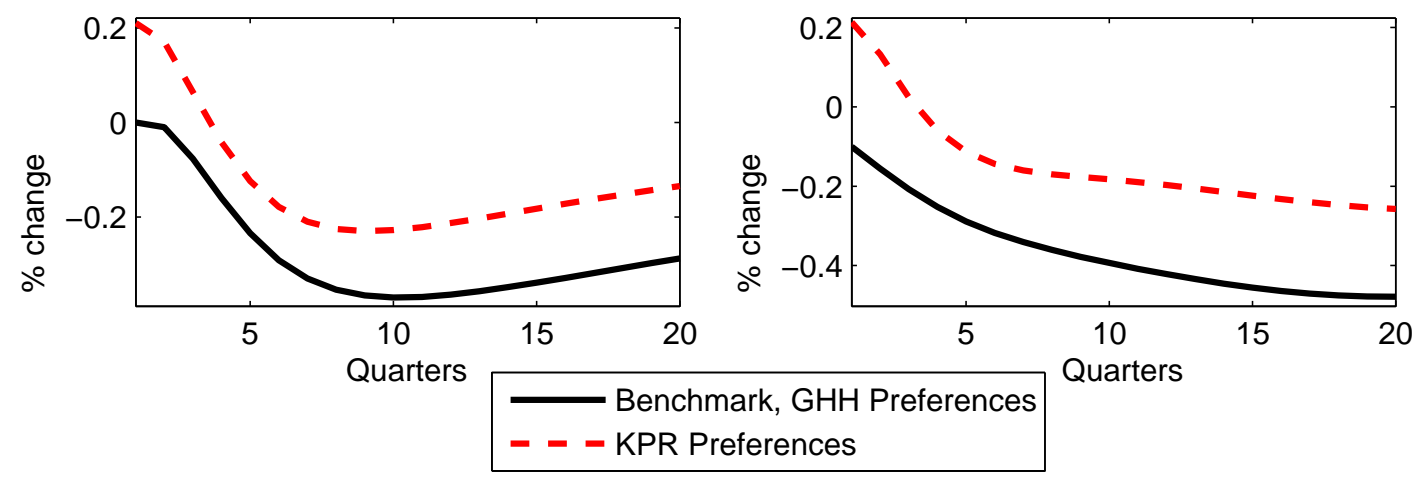

